\title{
"White" Space and Organic Claims on Food Packaging: Communicating Sustainability Values and Affecting Young Adults' Attitudes and Purchase Intentions
}

\author{
Kostoula Margariti
}

Citation: Margariti, K. "White" Space and Organic Claims on Food Packaging: Communicating Sustainability Values and Affecting Young Adults' Attitudes and Purchase Intentions. Sustainability 2021, 13, 11101. https://doi.org/ $10.3390 /$ su131911101

Academic Editor: Mario D’Amico

Received: 30 August 2021

Accepted: 5 October 2021

Published: 8 October 2021

Publisher's Note: MDPI stays neutral with regard to jurisdictional claims in published maps and institutional affiliations.

Copyright: (C) 2021 by the author. Licensee MDPI, Basel, Switzerland. This article is an open access article distributed under the terms and conditions of the Creative Commons Attribution (CC BY) license (https:// creativecommons.org/licenses/by/ $4.0 /)$.
Department of Economics, Aristotle University of Thessaloniki, 54124 Thessaloniki, Greece; kostmar88@gmail.com

\begin{abstract}
The development of organic food products has proliferated over the past few decades, alongside the use of "white" space on products' packaging as an element that communicates quality and sustainability values. Despite a growing interest towards green products, sustainable business practices and aesthetics, there is not enough evidence on how specific design elements (i.e., "white" space) of organic food packaging could affect consumers' brand perceptions, attitude towards the brand (Abr) and purchase intentions (PI). The present study seeks to unveil the role of "white" space as a packaging design element on the effectiveness of organic food products. Based on a content analysis of 406 international packaging designs it establishes the widespread coexistence of organic products with extended, in shades of gray "white" space. A between-subjects experiment with 305 young adults builds on the associations between "white" space and sustainability, and provides evidence on the proposed serial mediation model with perceived naturalness, quality and trustworthiness, and Abr as mediators in the relationship between organic food products and PI, especially when the packaging uses extended "white" space. Pertinent managerial implications with respect to effective packaging design that promotes sustainability values and generates positive attitudes and behaviors towards organic foods are underlined.
\end{abstract}

Keywords: organic food; "white" space; perceived quality; perceived naturalness; perceived trustworthiness; attitude towards the brand; purchase intention

\section{Introduction}

Phenomena such as resource constraints, rise of world population alongside environmental degradation constitute a "wake-up call" on sustainability [1] that has turned out to be a mainstream issue in both the academic and business world [2]. Sustainability is a multifaceted construct that reflects challenges for both companies and individuals. Companies try to respond to the needs of their shareholders and stakeholders, contribute to the society and environment without endangering the transfer of further improvements to future generations [3]. In addition to the interest of the business world in sustainable phenomena and sustainable marketing strategies in the recent years, academics seek to provide a consolidated definition of sustainable marketing. An exceptional example is that of Martin and Schouten (2014, p. 18) [4] according to whom sustainable marketing is the creation, communication and delivery of value to customers in a way that both natural and human capital are preserved or enhanced throughout. Among other sustainable marketing strategies, companies integrate ethical and environmental values to construct novel products with longer lifespan [5], deliver sustainable goods [6], design eco-friendly and sustainable packaging [7] and support recycling and reusing [8].Along a similar vein and from the viewpoint of individuals, they consume more responsibly, using green and ecofriendly products $[9,10]$, saving energy $[11,12]$ and realizing in general that such practices might improve the quality of their own lives as well as for the next generations, society and environment. 
The development and consumption of sustainable products reign in the heart of the above-mentioned sustainability trend [13]. Organic foods are produced by the implementation of integrated sustainable patterns of production, respect the carrying capacities of natural ecosystems and sustainability standards and carry specific, organic farming certification [14]. In recent years, a significant body of research has paid attention to organic food products and the drivers that affect consumers' attitudes and behaviors towards them [15-17]. The increase in environmental and sustainability concerns as well as the adoption of healthier dietary choices leads individuals towards the consumption of organic food products [18]. There are several examples of food companies that focus on producing and providing reliable healthy choices, such as bio or organic products. For instance, Loulis Mills constitutes an example of a Greek company that, among others, operates on baking flours, whole-wheat bran and pastry and baking mixes. As mentioned in its mission, the company produces qualitative and innovative raw material, as well as it provides high quality services in the food industry, respecting and creating value for its customers, employees, shareholders and society. The company tries to be socially and environmentally responsible by consciously implementing a Quality Management System for the production and trading its products. Grounds for Change is a family-owned, coffee-roasting company that contributes to the society, business and environment by producing certified organic and shade-grown coffee, cultivated by farmers that use renewable resources and conservation. It uses $100 \%$ post-consumer recycled paper on products' packaging. Another company, Eden Organic, the oldest organic food producer in North America, operates on dry grocery organic food and fruits, canned food, juices, spices and herbs, using non-GMO ingredients, bisphenol-A-, pesticide- and irradiation-free [19].

Eco-friendly packaging contributes to the development of a brands' sustainability profile $[20,21]$. Sustainable packaging refers to the creation of an appropriate, green commodity form [21] that attracts attention, enhances the perception of product sustainability and persuades consumers to buy it [22]. There are several examples of companies that set sustainable packaging of their products as a priority of their marketing strategies. Delifrance constitutes a Greek company that uses sustainable packaging for its products (i.e., croissants), trying to keep them safe and fresh. $85 \%$ of the packaging is made out of paper, while $99.8 \%$ of them is recycled. McDonald's announced that its packaging will be $100 \%$ renewable and recycled by 2025 , while H\&M developed $80 \%$ recycled paper bags that transform into a clothes hanger. Along this vein, IKEA invests in biodegradable types of packaging made from mycelium fungus [23].

The sustainability values of a product are not communicated only through eco-friendly materials and explicit organic claims on the packaging but also through aesthetics. Defining aesthetics in the context of sustainable product design is very difficult [24-26] since concepts such as aesthetics and sustainability are fluid, complex, qualitative. Particularly, aesthetics is subjective and open to each individual's perception and interpretation, and thus difficult to be defined and measured. Yet, in the recent years, there have been several academics that tried to define sustainable aesthetics. Among others, Magnier and Crie (2015) [27] define sustainable package design as the design that explicitly or implicitly communicates the eco-friendliness of packaging through its structure, graphical or iconographic and informational elements. Additionally, Zafarmand, Sugiyama and Watanabe (2003) [28] examine aesthetics in the background of sustainable product design, as for example green and eco-design. Their study underlines seven aesthetic attributes that can promote product sustainability, such as simplicity and minimalism. In this vein, Chim and Blebea (2013) [29] identify simplicity, natural forms, colors and materials as fundamental eco-attributes, among others.

"White" (or otherwise called negative or blank) space represents one of the most significant design elements of minimalism [30-32] that enhances perceived trustworthiness and quality of the brand and leads to favorable Abr and PI. Chim and Blebea (2013) [29] note that there are associations between the use of "white" space, as a minimal design element, and sustainable design aesthetics, since "white" space liberates the stimulus from 
too much information and excessiveness. In particular, designing or redesigning a package with less materials (i.e., colors or ornamentations), with minimal but smart design can be an optimal aesthetic solution for a sustainable design that signifies the reduction of waste. An exceptional example of a brand that incorporates "white" space on its packaging design is Biotika, a Polish manufacturer of soy candles and scented waxes that uses simple forms, natural and organic colors that enhance the brand's image [23].

Nevertheless, despite the growing interest towards sustainable business strategies, such as the development of sustainable food products [33,34], the shift towards eco-friendly, aesthetic package design [17] and the importance of "white" space as a design element [32], respectively, no previous study has ever examined if and to what extent the parsimonious "white" space could moderate the relationship between an organic food product, attitude towards the brand (Abr) and purchase intention(PI), via particular product values such as, perceived naturalness, perceived quality and perceived trustworthiness. Importantly, considering that "white" space constitutes a modest but rhetorical design tool that implicitly signals high quality and trust [32], it would be of high academic interest to examine whether its presence in the organic food packaging could serve as a way to indirectly communicate sustainable values and in turn lead to positive consumers' attitudes and intentions. Addressing this research void, the current study has a twofold objective: It suggests that an organic food product positively affects Abr and in turn PI, via perceived naturalness, perceived quality and perceived trustworthiness. Furthermore, it suggests that the above-mentioned path generates a more positive Abr and in turn enhanced PI, in the presence of extended rather than limited "white" space in the packaging of the product. The discussion is based on the outcomes of a content analysis of contemporary organic products' packaging and an experimental study conducted on an organic food product. Along these paths of analysis, the present study highlights significant research gaps that act as avenues for potential contribution.

First, a content analysis of international organic products' packaging constitutes a timely response to the popular business trend of incorporating extended "white" space in the packaging of organic (food) products. To the best of the author's knowledge, this is the first attempt to content analyze packaging of organic products in the context of a minimalist layout. A significant body of research has already examined the impact of organic food products on consumers' attitude and behavior [35,36] and the effectiveness of "white" space in advertising context [30,31], as two distinct elements. In the prism of an all-inclusive approach, the present paper seeks to unveil if and to what extent these two elements coexist in the business world.

Second, this study tries to examine the impact of organic food products on consumers' responses. An online experiment on young adults is conducted to test the proposed serial mediation model with perceived naturalness, perceived quality, perceived trustworthiness and Abr as mediating factors in the relationship between organic food products and PI.

Third, the presence of extended "white" space in organic food packaging is discussed as a significant design element affecting the effectiveness of organic food products. Prior studies associate "white" space with concepts of high quality and trust which in turn lead to favorable Abr and PI [32]. At the same time, Zafarmand, Sugiyama and Watanabe (2003) [28] suggest that simple aesthetics (i.e., the ones communicated by "white" space) promote products' sustainable values and constitute a significant environmental dimension of design practices that highlight the products' naturalness of ingredients and restrained industrial process [29]. Building on the above, this study attempts to shed light on the synergy of "white" space and organic food products on Abr and PI, via particular sustainable values. The author suggests that "white" space serves as an optimal aesthetics for an organic food product that could exert positive attitudes and behaviors through promoting products' perceived naturalness, trustworthiness and quality.

All in all, the present study investigates whether and to what extent minimal "white" space could be an optimal aesthetic cue for the packaging of an organic food product. As 
Chim and Blebea (2013, p. 55) [29] argue, sustainability is a blooming design movement in need of suited aesthetics, thereby, something that minimal "white" space could provide.

\section{Literature Review}

\subsection{Organic Food Products}

Organically farmed food products are a specific example of sustainable products $[37,38]$ that include phosphate-free detergents, are farmed with no pesticides and their package is made of recycled paper or other materials [39]. Organic foods' production, distribution and other marketing activities are built on environmental, regulatory standards in a manner to increase efficiency [40], maximize profits [41] and reduce costs [42]. Terms such as "green" or "organic" infer that food originates from unpolluted and hygienic environment are reliable and of high quality.

As far as it concerns organic food products, a significant body of research has focused on the impact of eco-friendly foods on perceived quality $[18,43]$. Perceived quality of a product is defined as the perceived superiority and excellence of the product when compared with competing alternatives [44]. Lee, Shimizu, Kniffin and Wansink (2013) [45] provide evidence that product sustainability has a positive impact on perceived quality of the product. Consumers perceive sustainable products to be better with respect to taste, quality, safety and naturalness, and to be more beneficial with respect to individuals' health, the environment and the economy [46]. Furthermore, eco-friendly and responsible actions adopted by the company in the production of the product can enhance the believability and reliability of claims such as "green", "organic" and "natural" which in turn might affect consumers' perceptions regarding the sustainability of the product [47], attitude and behavior $[17,35]$.

\subsection{Packaging Design and Sustainable Aesthetics}

Explicit organic claims on organic food packaging are not the only ones that might signify products' sustainable values. Previous research has paid significant attention to visual aesthetics in package forms and designs $[48,49]$ since they constitute an important tier in products' effectiveness. According to Underwood (2003) [50], packaging is associated with strategic decisions of the marketing mix and plays a pivotal role in positioning decisions. McNeal and Ji (2003) [51] suggest that packaging contributes to the functionality, safety and preservation of the product, adds to marked-up prices, and most importantly constitutes a significant element of the visual communication of the brand that seeks to inform and persuade at the point of sale and consumption. In addition, Jordan (1998) [52] proposes that besides usability, sense of security, pride and other attributes, there is also aesthetic pleasure to be communicated and provided by a visually attractive package design. Along a similar vein, Bloch (1995) [53] argues that aesthetic design of a packaging creates initial impressions and perceptions about the product that might lead to pleasure, stimulation and purchase. Additionally, it is important for packaging to communicate consistent brand and product values to achieve a suitable aesthetic and visual level (Nancarrow, Wright and Brace 1998) [54]. Packaging might attract attention, communicate values of the product [55], communicate messages with respect to the quality and function of the product [56], generate positive attitudes, lead to evaluation of products [57] and enhanced purchase intentions [57,58]. According to Thomas and Capelli (2018) [59], packaging design enhances positive attitudes and evaluations, while according to Underwood et al. (2001) [60], it contributes to the establishment of trust between brands and consumers.

A product is characterized by both extrinsic (i.e., the brand name and the packaging) and intrinsic (i.e., the quality) attributes, which add to the aesthetic perception of the product. Assuming that extrinsic and intrinsic cues are coordinated in an eco-friendly manner, they might form and affect consumers' perception about the products' sustainable profile too [49]. For instance, food companies can communicate the sustainability of their products via manipulating sustainable extrinsic attributes, such as adding "organic" or "green" claims [27]. Interestingly, the study of Zafarmand, Sugiyama and Watanabe 
(2003) [28] highlights the aesthetic characteristics of (un)sustainable products, examine the relationship between product aesthetics and sustainability, while they argue that such association might affect consumers' imagination, satisfaction, attitude, behavior and taste towards the product and the brand. In this vein, Steenis et al. (2018) [61] demonstrate the impact of sustainable design strategies on purchase intentions, while Balconi, Sebastiani and Angioletti (2019) [62] suggest that design aesthetics are associated with sustainability issues, thereby preserving the environment, and contributing to society, business and culture. Similarly, Magnier and Schoormans (2015) [63] demonstrate that aesthetic design of sustainable products increases choice likelihood.

\section{3. "White" Space and Design Simplicity}

In the context of aesthetic design, "white" space, a design quality of minimalism that originates from the 20th century architecture and arts, signifies design simplicity and parsimony [64]. "White" space as a rhetorical design element has attracted widespread attention in advertising field, according to which despite its apparent simplicity and modesty, it doesn't come with zero meanings, rather it can indirectly communicate its own messages and attribute its values tothe advertised brand [30,31]. Pracejus, Olsen and O'Guinn (2006) [32] demonstrate that "white" space signals timelessness, high quality, high aesthetics, trustworthiness and elegance. Furthermore, "white" space makes the stimulus seem uncluttered [65], cleaner [66], while it rules the aesthetics, harmony and sequence of the whole. According to Kwan, Dai and Wyer (2017) [66], the stimulus that incorporates extended "white" space becomes more tasteful and aesthetic. The simplicity (as the one exerted by "white" space) constitutes a significant dimension of visual design that affects individuals' aesthetic perceptions and reactions [67]. Previous research illustrates that design simplicity enhances positive first impressions and promotes the beauty and the clarity of the stimulus due to the high visual harmony and unity [68]. Additionally, Karvonen (2000) [69] associates a simple aesthetic design with higher usability.

Building on the above, the first study of the present paper seeks to examine if and to what extent "white" space exists in the packaging of organic (food) products in the business world. Additionally, Study 1 provides a consolidated basis for the subsequent examination of consumers' attitudes and intentions towards organic food packaging with "white" space, via perceived naturalness, perceived quality and perceived trustworthiness (Study 2).

\section{Study 1}

\subsection{Research Questions}

A wide range of organic food product packaging worldwide incorporates "white" space. The packaging of "Five" organic olive oil, Barilla Bio, "Gourmet Organic" herbs, "Lezi Olive Oil" and "RHL Organic" face serum are some exceptional examples of organic products that incorporate "white" space on their packaging. Furthermore, prior research on organic products has used packaging stimuli that incorporate an extended "white" space to evaluate consumers' perceptions, attitudes and behaviors towards the brand [27]. However, despite the apparent trend in the business and academic world for organic products with minimal packaging designs (i.e., extended vs. limited "white" space, monochrome vs. no monochrome "white" space and in shades of grayscale vs. not in grayscale colors "white" space), previous studies have never examined if and to what extent "white" space appears in the packaging of organic (food) products, nor did they look into "white" space design characteristics in organic food packaging. Thus, a content analysis of international organic products' packaging seeks to confirm the popular business trend of incorporating extended "white" space in the packaging of organic food products. Study 1 aims to address these issues and in particular:

RQ1: To what extent does the packaging of organic products incorporate "white" space (i.e., extended, monochrome and in shades of gray space) worldwide? 


\subsection{Methodology \\ 3.2.1. Sample}

Packaging of the World (www.packagingoftheworld.com, accessed on 11 June 2021) constitutes one of the most trusted archives of packaging content $[70,71]$ that provides the sampling frame for the packaging to be content analyzed. Since Study 1 focuses on analyzing the visual content format, content analysis seems an appropriate method. Overall, 406 international packaging designs were selected from a research population of 637 worldwide packaging uploaded from the site Packaging of the World from 2019 until 2021. The consideration set consisted of an organic product.

\subsubsection{Coding Scheme and Procedure}

Organic products were classified into those belonging in the food and beverages category and those not. The presence or the absence of an extended, monochrome and in shades of gray "white" space [30] was recorded. Two independent coders (a male and a female), trained on the task over a 72-packages sample, analyzed all organic products' packaging. Discrepancies during coding were resolved by a third coder. Reliability coefficients ranged from 0.90 to 0.92 , demonstrating a satisfactory inter-coder agreement (Table 1 ).

Table 1. Typology and coding values (Study 1).

\begin{tabular}{|c|c|c|c|}
\hline $\begin{array}{l}\text { Variables and } \\
\text { Sub-Variables }\end{array}$ & Brief Description & Coding & $\begin{array}{l}\text { Inter-Coder Reliability } \\
\text { (Cohen's Kappa) }\end{array}$ \\
\hline \multicolumn{4}{|l|}{ Organic Products } \\
\hline Organic foods & $\begin{array}{l}\text { The organic product is included in the food and } \\
\text { beverage category or not }\end{array}$ & $\begin{array}{l}0=\text { other than organic } \\
\text { food } 1 \text { = organic food }\end{array}$ & 0.91 \\
\hline \multicolumn{4}{|l|}{ "White" Space } \\
\hline Extended space & $\begin{array}{c}\text { The extent of "white" space compared to the } \\
\text { total ad layout }\end{array}$ & $\begin{array}{c}0=(<1 / 2 \text { of the total } \\
\text { ad layout }) \\
1=(\geq 1 / 2 \text { of the total ad } \\
\text { layout }\end{array}$ & 0.90 \\
\hline Monochrome space & $\begin{array}{c}\text { "White" space is monochrome (unique color) or } \\
\text { not (multiple color) }\end{array}$ & $\begin{array}{l}0=\text { not monochrome } \\
1=\text { monochrome }\end{array}$ & 0.92 \\
\hline Space in grayscale & $\begin{array}{l}\text { "White" space is in shades of gray (black, white } \\
\text { or gray) or not (other than black, white or gray) }\end{array}$ & $\begin{array}{l}0=\text { not grayscale } \\
1 \text { = grayscale }\end{array}$ & 0.91 \\
\hline
\end{tabular}

\subsection{Results}

Single sample chi-square tests demonstrated that organic food and beverages prevail (77.83\%) in the organic market, followed by cosmetics and skincare products $(22.17 \%)$, $\left(\chi^{2}=130,296, \mathrm{df}=1, p<0.001\right)$. No other product categories were detected during the content analysis of the sample.

Single sample chi-square tests also proved that most organic products' packaging includes an extended $\left(74.14 \%, \chi^{2}=94,621, \mathrm{df}=1, p<0.001\right)$ and in shades of gray "white" space $\left(55.42 \%, \chi^{2}=4768, \mathrm{df}=1, p<0.05\right)$ (RQ2). However, there were no statistically significant differences with respect to whether the "white" space was monochrome (51.48\%) or not $(48.52 \%)\left(x^{2}=355, \mathrm{df}=1, p>0.05\right)$ (Table 2$)$.

Table 2. The design characteristics of "white" space incorporated in the packaging of organic products (Study 1).

\begin{tabular}{cccc}
\hline & \multicolumn{3}{c}{ Types of “White Space” } \\
\hline & Extended Space & Monochrome Space & Space in Grayscale \\
\hline Organic products & $\%(\mathrm{~N})$ & $\%(\mathrm{~N})$ & $\%(\mathrm{~N})$ \\
& $74.14(301)$ & $51.48(209)$ & $55.42(225)$ \\
\hline
\end{tabular}




\subsection{Discussion}

Study 1 proves that organic food and beverages is the most common product category in the organic market. Additionally, most of the content analyzed packaging includes an extended and in shades of gray (white, black and gray) "white" space. Study 1 is the first content analysis on worldwide organic food product packaging at various levels of "white" space. The study unveils that organic foods extensively incorporate extended and in shades of gray "white" space. This outcome implies that in the business world, "white" space is incorporated in the packaging of organic (food) products perhaps as a way to communicate brands' sustainable values and in turn positively affects consumers' attitudes and intentions. Subsequently, building on the outcomes of Study 1, a follow-up experiment seeks to determine (a) the effect of organic food products on consumers' attitudes and purchase intentions, and (b) whether the use of "white" space in organic food packaging affects consumer attitudes and purchase intentions, via the mediating effect of perceived naturalness, perceived quality and perceived trustworthiness.

\section{Study 2}

\subsection{Hypotheses Development}

\subsubsection{Perceived Naturalness, Quality and Trustworthiness of Organic Food}

Perceived naturalness: Sijtsema et al. (2016) [72] argue that "naturalness" refers to something that has not been chemically produced but is made of plants. Tobler, Visschers and Siegrist (2011) [73] show that product sustainability is associated with perceived naturalness, while Magnier, Schoormans and Mugge (2016) [27] demonstrate that product sustainability leads to higher levels of perceived naturalness for the product. Particularly, they suggest that perception of sustainability generates higher levels of perceived product naturalness. Additionally, Rozin (2005) and Lurando and Saintives (2013) [74] suggest that consumers evaluate natural products as healthier, more appealing to the senses, ecofriendly and aesthetic.

Perceived quality: According to Moore and Baldwin (1993) [75] anything natural is inherently good (i.e., of good quality) while anything artificial is potentially bad (i.e., of bad quality). Previous studies have demonstrated that individuals show a preference towards natural, environmentally friendly products with minimum human or technology intervention [74,76].Verbeke and Ward (2006) [43] prove that perceptions of product values, such as quality, are affected by the provided information, while Pieniak, Verbeke, Vermeir, Brunsy and Olsen (2007) [77] prove increased consumers' interest towards direct indications of food quality. Van Doorn and Verhoef (2011) [78] demonstrate that consumers perceive food products with an organic signal on their packaging as having higher quality than the non-organic or conventional food products. Moreover, Lee and Yun (2015) [18] and Lee et al. (2013) [45] provide evidence that organic food products are ranked as being of higher quality because they are healthier and tastier. Generally, food indications, logos or labels displayed on packaging, such as "green" or "organic farming", are highly appreciated.

Perceived trustworthiness: Consumers demand authentic indicators on packaging of organic foods that reduce perceived risk associated with their consumption. In the business world, there exist numerous cases of deceptive green marketing, or otherwise called green-washing, which provide consumers with exaggerated, false or irrelevant information with respect to the products' sustainable values, which in turn make consumers more skeptical towards green marketing. Such risks highlight the importance of trust in organic food consumption. Trust is considered as a leading factor for the growth of organic food sector $[79,80]$ and it is essential to communicate the superiority and benefits important to consumers. According to Konuk (2018, p. 143) [81], trust in organic foods is "consumer's confidence in a particular organic food product's reliability, integrity and safety". Interestingly, a significant body of research verifies the relationship between organic food, trust and consumers' behavior, especially that exerted by labeling and certification processes $[79,82-84]$. Hence, it is hypothesized that: 
Hypothesis 1 (H1). Organic food products generate higher levels of (a) perceived naturalness, (b) perceived quality and (c) perceived trustworthiness than conventional food products.

4.1.2. "White" Space on Organic Food Packaging: The Impact on Perceived Naturalness, Quality and Trustworthiness

Packaging design and aesthetics can be highly beneficial in a commercial manner, thereby, boosting the product's visual appearance [85]. According to Underwood (2003), packaging becomes part of the buying and consuming process, while it sometimes reflects the ingredients that are essential for the product to function. In the context of semiotics, packaging design becomes part of communicating the brand's identity, qualities and meaning [77], thereby, consumers use packaging design to evaluate and draw inferences about the product and the brand [78]. For instance, packaging design cues, such as color or shape, can affect consumers' perceptions with respect to the product's content [79], such as products' quality [17]. In the same vein, individuals make inferences about product values and qualities based on sustainability signals $[17,80]$, such as its naturalness or healthiness [17] or its sensory characteristics (i.e., taste) [81].

Simplicity, as a fundamental characteristic of minimal design, is characterized by moral dimensions and inner qualities, such as harmony, clarity and truth that go beyond aesthetics $[29,82]$. Simplicity in design can affect consumers' attention, attitude and purchase intention [83] since it contributes to the criticism of contemporary values of excess and ornamentation via the expression of essentiality and truth. Favier, Celhay and PantinSohier (2019) [84] demonstrate that consumers prefer more a simple than a complex package design which infers design aesthetics and brand values, such as modernity, success and authenticity. Furthermore, the presence of "white" space in (logo) design has also positive impact on brand evaluations on accounts of perceptual fluency and perceived clarity and is associated with consistent, sophisticated, sincere and exciting brand personality [85]. In prior studies, creatives have argued that using "white" space serves the purpose of communicating brand trust, integrity, reliability and leadership [32]. Importantly, Pracejus, Olsen and O'Guinn (2006) [32] show that "white" space in advertising design signifies brand quality and trust which in turn lead to positive Abr. In the context of sustainability, Chim and Blebea (2013) [29] discuss some associations between minimalism and sustainability suggesting that among others, simplicity, quality and clarity represent some of the concurring principles of these two movements. In this vein, Zafarmand, Sugiyama and Watanabe (2006) [28] demonstrate that simplicity in product aesthetics promotes product sustainability.

Building on the above, it is assumed that when "white" space is incorporated on the packaging design of an organic food product, consumers might draw inferences about the qualities of the brand, since "white" space constitutes a rhetorical design element that indirectly communicates brands' values (i.e., quality etc). Particularly, it is expected that the simplicity expressed by the presence of "white" space will enhance perceived naturalness, quality and trustworthiness of the organic food. Therefore, it is suggested that:

Hypothesis 2 (H2). Organic food products with extended "white" space on packaging generate higher levels of (a) perceived naturalness, (b) perceived quality and (c) perceived trustworthiness.

\subsubsection{Perceived Naturalness, Perceived Quality, Perceived Trust and Abr}

Eco-friendly products can enhance the corporate image and enable companies to differentiate their offering from competitors [86,87]. Perceived quality of a product could have a significant impact on a company's profitability, since consumers usually express their preference to pay more for products that are perceived of higher quality [88]. Furthermore, consumers show preference towards natural products of high quality. Sijtsema et al. (2016) [72] suggest that individuals form positive attitudes towards natural and environmentally friendly aspects of the product. Additionally, Chen et al. (2019) [89] prove that trust serves as an antecedent of attitude towards an organic food product. Moreover, Martinho et al. (2015) [90] show that consumers form favorable attitudes toward packaging 
that communicates a product's sustainable profile that is associated with purchase likelihood [61]. Building on the above, it is expected that the perceived naturalness, perceived trustworthiness and perceived quality of organic food products, especially when combined with extended "white" space signals high quality and trust [32] and generates positive Abr. Hence, it is suggested that:

Hypothesis 3 (H3). (a) Perceived naturalness, (b) perceived quality and (c) perceived trustworthiness have a positive effect on Abr.

\subsubsection{Abr and PI}

According to Ajzen (1991) [91], attitudes affect intentions, while the more favorable the attitude the greater the intention to execute the behavior. Empirical evidence demonstrates a significant relationship between organic food products, attitudes and purchase intentions [92-95]. For instance, Van Doorn and Verhoef (2011) [96] provide evidence that consumers express high purchase intentions towards sustainable food products with high quality. Similarly, Chen and Chang (2012) [97] show that consumers' purchase intentions are positively affected by green products. Consumers form positive attitudes that lead to enhanced purchase intentions towards sustainable products and sustainable consumption $[46,98]$.

Prior research also demonstrates that purchase intention is positively affected by aesthetics [99,100]. Interestingly, Charter and Tischner (2017) [101] argue that aesthetic appeals can lead to increased purchases while products' aesthetics might impact social and economic dimensions of sustainability. Bragd (1997) [102] and James (1997) [103] suggest that products' aesthetics can impact the socio-cultural and economic dimensions of sustainability, via the notions of "image making" and "symbolic loading", respectively. Product packaging constitutes a crucial driver of consumers' purchases, since it is the first thing that individuals see before making their final decision [104,105]. Moreover, Magnier and Schoormans (2015) [63] demonstrate that sustainable packaging positively influences purchase intentions, while Bloch, Brunel and Arnold (2003) [106] prove that consumers are attracted by the visual appearance of the products which in turn affects their purchase intention. Additionally, Pracejus, O'Guinn and Olsen (2013) [31] unveil that "white" space as a design element can affect consumers' purchase intentions. Hence, it is expected that attitude towards an organic food brand, especially when combined with extended "white" space, will lead to increased purchase intentions. The following hypothesis is advanced:

Hypothesis 4 (H4). Abr has a positive effect on PI.

Overall, the current study suggests that the sustainable profile of an organic food product will be enhanced by the presence of "white" space on its packaging and will lead to positive attitude towards the brand and increased purchase intention. Particularly, it is suggested that an organic food product (especially when it incorporates "white" space on its packaging) will positively affect perceived quality, naturalness and trustworthiness, which in turn will positively affect Abr and PI. Perceptions of high quality, naturalness and trustworthiness of a sustainable, organic food product are enhanced due to the presence of "white" space, which according to previous research [32] is associated with concepts of high quality, simplicity, timelessness and trust. Furthermore, "white" space, as a design element of minimalism, constitutes a visual trope that communicates brands' values (i.e., high quality, trust and high aesthetics) [32] in an indirect manner, which affects Abr. Thus, the conceptual model of the present study also suggests that perceptions of high quality, naturalness and trustworthiness of an organic product (especially when combined with extended "white" space) will generate positive Abr and in turn enhanced PI. The current study suggests that the presence of "white" space serves as a design element that implicitly communicates products' values without burdening the presence of explicit organic claims. Extant literature suggests that packaging design constitutes a communication medium that conveys brand identity [84] and affects purchase intentions [107]. According to 
Underwood (2003) [50], packaging design offers functional, experiential and symbolic benefits to the customers, thereby, strengthening the relationship between consumers and brands. Specifically, as underlined by previous studies, consumers exert positive attitudes and enhanced purchase intentions towards sustainable products [46] and sustainable aesthetics in packaging design [63]. Thus, building on the above, it is expected that an organic product (especially combined with extended "white" space) will generate positive Abr and in turn enhanced PI, via increased perceived quality, perceived trustworthiness and perceived naturalness (Figure 1). Thus, it is suggested that:

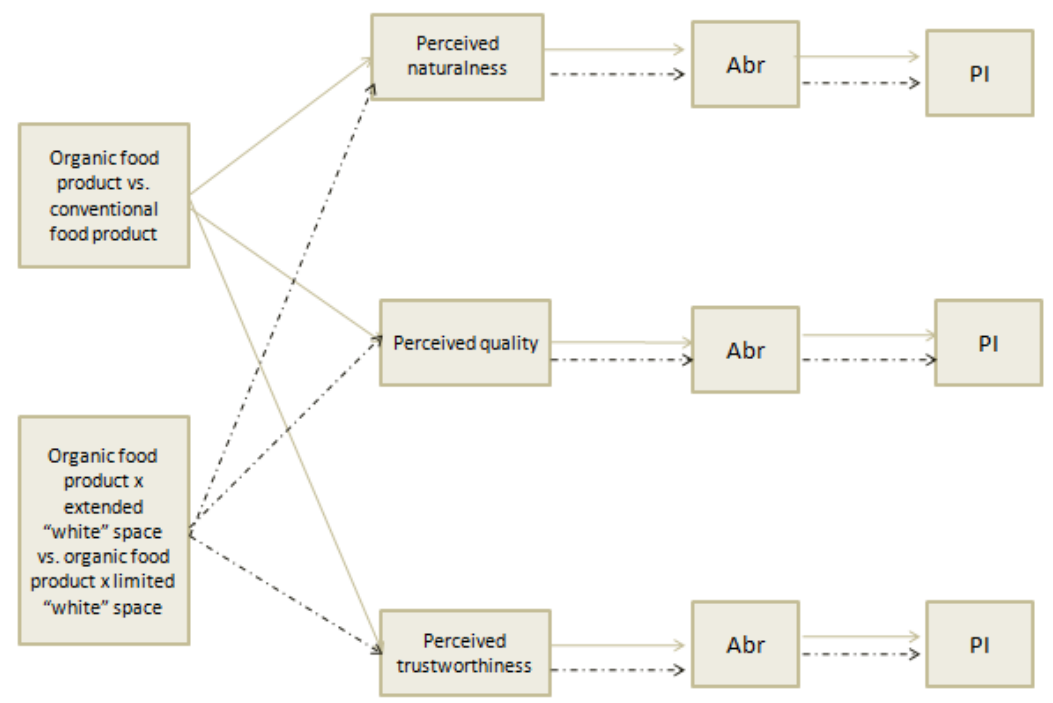

Figure 1. Conceptual path model 1 to 6 (merged) of Study 2; Note: Solid lines and bold numbers indicate the effects of organic food product; Dashed lines indicate the effects of organic food product with "white" space.

Hypothesis 5 (H5). An organic food product (vs. a conventional product) has a positive effect [through (a) perceived naturalness, (b) perceived quality and (c) perceived trustworthiness to Abr] on PI.

Hypothesis 6 (H6). An organic food product with extended "white" space on its packaging (vs. with limited "white" space) exerts a positive effect [through (a) perceived naturalness, (b) perceived quality and (c) perceived trustworthiness to Abr] on PI (Figure 1).

\subsection{Methodology}

\subsubsection{Experimental Stimuli}

A 2 (organic vs. conventional product) $\times 2$ (extended vs. limited "white" space) experiment was conducted to examine hypotheses HypothesesH1-6. The experimental design was based on the definitions and settings of prior studies on organic food products [17] and "white" space [30,32]. A professional graphic designer developed a new packaging for an orange juice, with a fictitious brand name (Juicy Drink), in order to enhance external validity [108]. The four versions of the packaging included the same logo (an orange) next to the brand name, the same slogan (Enjoy life) and the same label with the ingredients and calories of the orange juice. The manipulation of the organic version included the claim " $100 \%$ organic" (organic product) (Figure 2a,c), whereas the conventional version included no organic claim (Figure 2b,d). Building on Pracejus, O'Guinn and Olsen (2013) [31], the manipulation of "white" space resulted in an extended, monochrome and in shades of gray (extended "white" space) (Figure 2a,b), or reduced "white" space condition (limited "white" space- multiple, colorful oranges) (Figure 2c,d). To manipulate "white" space, the size of the image surrounded by "white" space was altered and compared the extent of 
"white" space against the size of ad image, resulting in two versions of packaging with respect to "white" space, the extended and limited "white" space condition.
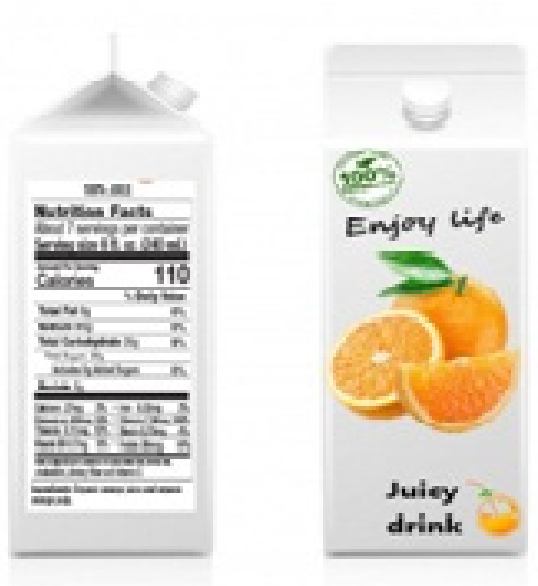

(a)

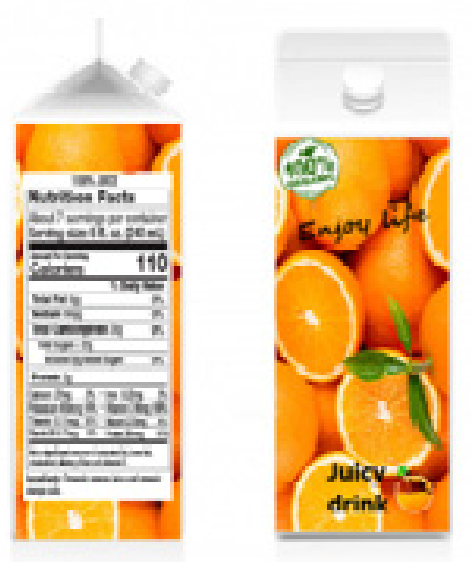

(c)
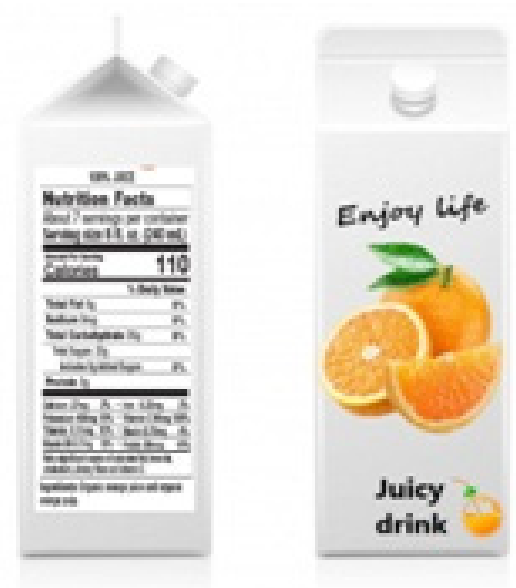

(b)

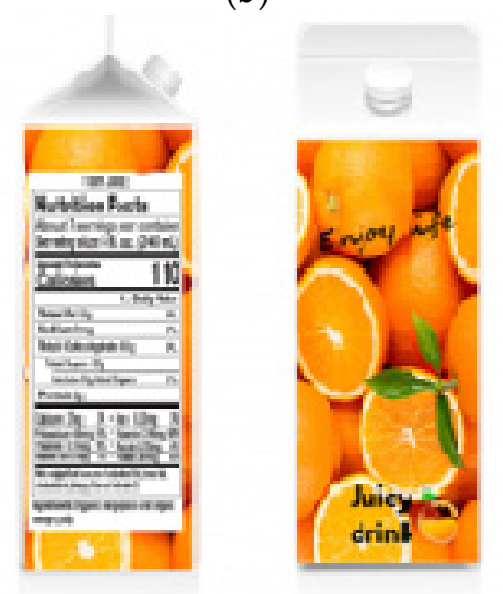

(d)

Figure 2. Experimental stimuli of Study 2. (a,b) extended "white" space, and (c,d) limited "white" space.

\subsubsection{Measures}

The translation and back-translation technique was used for the questionnaire development. The manipulation checks for "white" space were based on a 7-item scale (e.g., The packaging is minimal/reductive, $1=$ strongly disagree. $7=$ strongly agree). The manipulation checks for organic products were based on a 7-item scale [109] (e.g., This product is free from chemical pesticides and fertilizers, $1=$ strongly disagree. $7=$ strongly agree) and for packaging sustainability on a 3-item [61] (e.g., I expect that this new packaging deserves to be labeled as environmentally friendly, $1=$ strongly disagree. $7=$ strongly agree) scale. Perceived naturalness of the product was measured on a 7-item scale [110] (e.g., This product is healthy and natural, $1=$ strongly disagree. $7=$ strongly agree). Perceived quality was measured by a 5 -item scale [111] (e.g., This product would seem to be durable $1=$ strongly disagree. $7=$ strongly agree). Perceived trustworthiness was measured on a 5-item scale [112] (e.g., This product is $1=$ Unreliable. $7=$ Reliable). Attitude toward the brand was measured on a 4-item scale [113] (e.g., Do you think this is a good brand? $1=$ strongly disagree. $7=$ strongly agree) and purchase intentions were measured by a 3-item scale [114] (e.g., Do you consider buying this brand? $1=$ it is improbable . . $7=$ it is probable). Brand familiarity was measured on a single item scale [115] (e.g., This brand is, $1=$ completely unfamiliar. $7=$ completely familiar). All measures satisfied Cronbach's alpha criterion $(\alpha>0.7)$. Demographics, such as gender, age and education were also 
recorded. Embedded attention items (e.g., I have 17 fingers in my right hand) resulted in 18 responses being excluded from the analysis (Table 3 ).

Table 3. Items used in Study 2 and Cronbach's Alpha for each scale.

\begin{tabular}{|c|c|c|c|}
\hline Variables & Items & Responses & $\begin{array}{c}\text { Cronbach's } \\
\text { Alpha }\end{array}$ \\
\hline $\begin{array}{l}\text { "White" } \\
\text { space }\end{array}$ & $\begin{array}{l}\text { - The packaging is minimal/ reductive } \\
\text { - The packaging's style is very simple } \\
\text { - The content of the packaging is simplified } \\
\text { - The packaging incorporates minimal/reductive } \\
\text { - The packaging uses extended, empty space } \\
\text { The packaging's space is uncluttered } \\
\text { The packaging applies minimal/reductive } \\
\text { design approach }\end{array}$ & $\begin{array}{l}1=\text { Strongly disagree } \\
\ldots 7=\text { Strongly agree }\end{array}$ & 0.888 \\
\hline $\begin{array}{c}\text { Description } \\
\text { of organic } \\
\text { food } \\
\text { product }\end{array}$ & $\begin{array}{l}\text { - This product is healthy } \\
\text { - This product is of high nutrition value } \\
\text { - This is a product grown in harmony with nature } \\
\text { and product is free from chemical pesticides } \\
\text { - This product is produced with } \\
\text { environmentally/animal friendly techniques } \\
\text { This product is free from Genetically Modified } \\
\text { - } \begin{array}{l}\text { Organisms (GMOs) } \\
\text { should broducts coming from organic agriculture }\end{array} \\
\text { should be certified }\end{array}$ & $\begin{array}{l}1=\text { Strongly disagree } \\
\ldots 7=\text { Strongly agree }\end{array}$ & 0.866 \\
\hline $\begin{array}{l}\text { Packaging } \\
\text { sustainabil- } \\
\quad \text { ity }\end{array}$ & $\begin{array}{l}\text { - I expect that this new packaging is } \\
\text { environmentally friendly } \\
\text { I expect that this new packaging contributes a } \\
\text { lot to an improving environment } \\
\text { - I expect that this new packaging deserves to be } \\
\text { labeled as environmentally friendly }\end{array}$ & $\begin{array}{l}1=\text { Strongly disagree } \\
\ldots 7=\text { Strongly agree }\end{array}$ & 0.890 \\
\hline $\begin{array}{c}\text { Product } \\
\text { naturalness }\end{array}$ & $\begin{array}{l}\text { - This is an eco-friendly product } \\
\text { - This product is one of those that really respect } \\
\text { the environment } \\
\text { - You can immediately see that this product is } \\
\text { ecological } \\
\text { - This product is more ecological than most } \\
\text { The nutrition qualities of this product are good } \\
\text { - Tor the health } \\
\text { - This product is globally good for the health }\end{array}$ & $\begin{array}{l}1=\text { Strongly disagree } \\
\ldots 7=\text { Strongly agree }\end{array}$ & 0.896 \\
\hline
\end{tabular}


Table 3. Cont.

\begin{tabular}{|c|c|c|c|}
\hline Variables & Items & Responses & $\begin{array}{c}\text { Cronbach's } \\
\text { Alpha }\end{array}$ \\
\hline $\begin{array}{l}\text { Product } \\
\text { quality }\end{array}$ & $\begin{array}{l}\text { - The likelihood that the product would be } \\
\text { reliable is ... } \\
\text { - The workmanship of the product would be ... } \\
\text { - } \quad \text { This product should be of ... } \\
\text { The likelihood that his product is dependable } \\
\text { - } \quad \text { This product would seem to be durable ... }\end{array}$ & $\begin{array}{l}1=\text { very low } \ldots 7= \\
\text { very high } \\
1=\text { very low } \ldots 7= \\
\text { very high } \\
1=\text { very poor quality } \\
\ldots 7=\text { very high } \\
\text { quality } \\
1=\text { very low } \ldots 7= \\
\text { very high } \\
1=\text { strongly disagree } \\
\ldots \\
7=\text { strongly agree }\end{array}$ & 0.853 \\
\hline $\begin{array}{l}\text { Product } \\
\text { trustworthi- } \\
\text { ness }\end{array}$ & - $\quad$ This product is ... & $\begin{array}{l}1=\text { Undependable } \ldots \\
7=\text { Dependable } \\
1=\text { Dishonest } \ldots \\
7=\text { Honest } \\
1=\ldots \text { Unreliable } \ldots \\
7=\text { Reliable } \\
1=\text { Insincere } \ldots \\
7=\text { Sincere } \\
1=\text { Untrustworthy } \ldots \\
7=\text { Trustworthy }\end{array}$ & 0.952 \\
\hline $\begin{array}{l}\text { Brand } \\
\text { familiarity }\end{array}$ & - $\quad$ This brand is ... & $\begin{array}{l}1 \text { = Completely } \\
\text { Unfamiliar } \ldots \\
7 \text { = Completely } \\
\text { Familiar }\end{array}$ & - \\
\hline Abr & $\begin{array}{l}\text { - I like this brand } \\
\text { - I think this is a good brand } \\
\text { - I feel favorable towards this brand } \\
\text { - I would recommend this brand to others }\end{array}$ & $\begin{array}{l}1=\text { Strongly disagree } \\
\ldots \\
7 \text { = Strongly agree }\end{array}$ & 0.874 \\
\hline $\begin{array}{l}\text { Purchase } \\
\text { intention }\end{array}$ & $\begin{array}{l}\text { - I would consider buy this brand } \\
\text { - I would buy this brand if I found it in a shop } \\
\text { - I would not choose another (orange juice) brand } \\
\text { - It is possible that I will buy this brand }\end{array}$ & $\begin{array}{l}1=\text { Strongly disagree } \\
\ldots \\
7 \text { = Strongly agree }\end{array}$ & 0.849 \\
\hline
\end{tabular}

\subsubsection{Pretest}

A pretest of 77 participants $(20.77 \%$ male, 36.63 average age, holding a postgraduate degree) evaluated the manipulation of the organic food and "white" space conditions in the four packaging designs. All recorded variables satisfied Cronbach's alpha condition $(\alpha>0.7)$. The outcomes demonstrated that the perception of organic food product was higher in the organic food condition (Morg $=5.29, \mathrm{SD}=1.24$ ) compared to the conventional condition $(\mathrm{Mcon}=4.58, \mathrm{SD}=1.15)\left(\mathrm{t}_{\mathrm{org}}(71.7)=-2.57, p<0.05\right)$. Thus, the manipulation of organic food product was successful.

Additionally, it was found that perceived "white" space was significantly higher in the extended "white" space packaging designs (Mws $=5.23, \mathrm{SD}=1.09)$ compared to the limited "white" space packaging versions (Mlws $=4.55, \mathrm{SD}=0.1 .35)\left(\mathrm{t}_{\mathrm{ws}}(74.95)=-2.428\right.$, $p<0.05)$, indicating a successful manipulation of "white" space.

\subsubsection{Participants and Procedure}

Totally, 323 undergraduate students (55.08\% men, mean age: 22.48$)$ from Aristotle University of Thessaloniki (Greece) participated in the online study. Participants were assured that their answers would remain anonymous and would be used merely for research purposes. Participants were divided in four groups, to avoid inter group bias, each of them receiving a different version of the packaging stimulus: organic food product with extended "white" space, organic food product with limited "white" space, conventional food product with extended "white" space, and conventional food product with limited "white" space. They were asked to evaluate a new product for a fictitious orange juice brand and were awarded extra class credit for their participation. 


\subsection{Results}

\subsubsection{Manipulation Checks}

The outcomes of the study demonstrate that all independent variables were successfully manipulated. The organic claim on packaging design led to higher levels of perceived organic food product (Morg $=4.98, \mathrm{SD}=0.99)$ than the conventional version of product $($ Mcon $=4.58, \mathrm{SD}=1.14)($ torg $(291.11)=-3.25, p<0.05)$. Perceived "white" space, was also higher in the packaging designs with extended "white" space (Mws $=5.44, \mathrm{SD}=1.01)$ than those with limited "white" space (Mnws $=4.12, \mathrm{SD}=1.31)(\mathrm{tws}(282.81)=-9.859$, $p<0.001$ ). Packaging sustainability was higher in the case of organic product (Morg $=5.35$, $\mathrm{SD}=1.23)$ than the conventional product $(\mathrm{Mcon}=5.01, \mathrm{SD}=1.36)(\operatorname{torg}(296.01)=-2.292$, $p<0.05)$. However, there was no statistically significant difference was indicated between the extended "white" (Mws $=5.29, \mathrm{SD}=12.6)$ and limited "white" space (Mnws = 5.08, $\mathrm{SD}=1.34)((\operatorname{tws}(301.75)=-1.413, p=0.16)$.

\subsubsection{Main Results}

Six serial mediation analyses with multi-categorical independent variables (model 6 with 5000 bootstrap samples) were conducted [116]. Packaging type was the independent variable, perceived naturalness, perceived quality, perceived trustworthiness and Abr were the mediating factors, and PI was the dependent variable. The purpose of the study was to examine the superiority of organic food products over conventional ones, and that of organic food products including extended "white" space on their packaging over organic food with limited "white" space. Packaging type was dummy coded in two independent variables (organic versus conventional food product; organic food product with extended "white" space vs. organic food product with limited "white" space).

An organic food product (vs. conventional food product) leads to higher levels of perceived naturalness $(\beta=0.39, \mathrm{SE}=0.13, \mathrm{t}=3.03 p<0.001)$ and perceived quality $(\beta=0.32$, $\mathrm{SE}=0.12, \mathrm{t}=2.68, p<0.001$ ). Thus, Hypothesis H1a,b are supported. Nevertheless, there was no statistically significant difference between organic food products and conventional food products with respect to perceived trustworthiness $(\beta=0.15, \mathrm{SE}=0.12, \mathrm{t}=1.23$, $p=0.22$ ). Therefore, Hypothesis H1c is not accepted (Tables 4-6).

There was no statistically significant difference between the organic food product with extended "white" space and the organic food product with limited "white" space on perceived naturalness ( $\beta=0.24, \mathrm{SE}=0.17, \mathrm{t}=1.40, p=0.16)$. Therefore, Hypothesis H2a was not accepted. Nevertheless, the coexistence of organic food product and extended "white" space was found to be a marginal predictor of perceived quality ( $\beta=0.27$, $\mathrm{SE}=0.16, \mathrm{t}=1.75, p=0.08$ ) (Pritschet, Powell and Horne 2016) and a significant predictor of perceived trustworthiness ( $\beta=0.39, \mathrm{SE}=0.16, \mathrm{t}=2.38, p<0.05)$. Pritschet, Powell and Horne (2016) [117] note that many studies in the context of psychology label nearthreshold $\mathrm{p}$ values as "marginally significant". Particularly, according to their study the majority of 459 analyzed psychology articles label $p$ values between 0.05 and 0.1 as "marginally significant". Thus, Hypothesis H2b was marginally accepted and Hypothesis H2c was accepted (Tables 4-6).

Perceived naturalness had a significant positive effect on Abr in both organic food product (vs. conventional food product) $(\beta=0.52, \mathrm{SE}=0.05, \mathrm{t}=9.98, p<0.001)$ and organic food product with extended "white" space (vs. organic food product with limited "white" space) ( $\beta=0.41, \mathrm{SE}=0.08, \mathrm{t}=5.31, p<0.001)$ models in support of Hypothesis H3a (Tables 4-6). 
Table 4. Direct effects in mediation model and bootstrap 95\% confidence intervals for indirect effects of organic food product (and organic food product with "white" space) on PI with perceived naturalness and Abr as mediating factors in Study 2.

\begin{tabular}{|c|c|c|c|c|c|c|}
\hline & \multicolumn{2}{|c|}{$\begin{array}{c}\text { Perceived } \\
\text { Naturalness }\end{array}$} & \multicolumn{2}{|c|}{ Abr } & \multicolumn{2}{|c|}{ PI } \\
\hline & $\beta$ & $\mathrm{t}(303)$ & $\beta$ & $\mathrm{T}(302)$ & $\beta$ & $\mathrm{t}(301)$ \\
\hline $\begin{array}{c}\text { Organic } \\
\text { food product }\end{array}$ & $0.39^{* * *}$ & 3.03 & -0.14 & -1.14 & 0.20 * & 1.39 \\
\hline $\begin{array}{l}\text { Perceived naturalness } \\
\text { Abr }\end{array}$ & & & $0.52 * * *$ & 9.99 & $\begin{array}{l}0.36^{* * * *} \\
0.52^{* * *}\end{array}$ & $\begin{array}{c}6.79 \\
10.20\end{array}$ \\
\hline Mediation & & & & & IndexLLCI & ULCI \\
\hline \multirow[t]{2}{*}{$\begin{array}{c}\text { Organic } \\
\text { food product-> } \\
\text { Perceived } \\
\text { naturalness-> } \\
\text { Abr->PI } \\
\end{array}$} & & & & & \multicolumn{2}{|c|}{$0.11(0.0342,0.1942)$} \\
\hline & $\beta$ & $\mathrm{t}(155)$ & $\beta$ & $\mathrm{t}(154)$ & $\beta$ & $\mathrm{t}(151)$ \\
\hline $\begin{array}{l}\text { Organic food } \\
\text { product x } \\
\text { "white" space }\end{array}$ & 0.24 & 1.40 & -0.06 & -0.35 & 0.20 & 1.36 \\
\hline $\begin{array}{l}\text { Perceived naturalness } \\
\qquad \mathrm{Abr}\end{array}$ & & & $0.41^{* * *}$ & 5.31 & $\begin{array}{l}0.40^{* * *} \\
0.51^{* * *}\end{array}$ & $\begin{array}{l}5.23 \\
7.14\end{array}$ \\
\hline Mediation & & & & & Index & LLCI ULCI \\
\hline $\begin{array}{l}\text { Organic food product } x \\
\text { "white" space-> } \\
\text { Perceived } \\
\text { naturalness-> } \\
\text { Abr->PI }\end{array}$ & & & & & \multicolumn{2}{|c|}{$-0.05(-0.0114,0.1451)$} \\
\hline
\end{tabular}

Table 5. Direct effects in mediation model and bootstrap 95\% confidence intervals for indirect effects of organic food product (and organic food product with "white" space) on PI with perceived quality and Abr as mediating factors in Study 2.

\begin{tabular}{|c|c|c|c|c|c|c|}
\hline & \multicolumn{2}{|c|}{$\begin{array}{l}\text { Perceived } \\
\text { Quality }\end{array}$} & \multicolumn{2}{|c|}{ Abr } & \multicolumn{2}{|l|}{ PI } \\
\hline & $\beta$ & $t(303)$ & $\beta$ & $\mathrm{t}(302)$ & $\beta$ & $\mathrm{t}(301)$ \\
\hline $\begin{array}{c}\text { Organic } \\
\text { food product }\end{array}$ & $32 * * *$ & 2.68 & -0.14 & -1.36 & 0.16 & 1.68 \\
\hline $\begin{array}{l}\text { Perceived quality } \\
\text { Abr }\end{array}$ & & & $0.68^{* * *}$ & 12.99 & $\begin{array}{l}0.61^{* * *} \\
0.37^{* * *}\end{array}$ & $\begin{array}{l}10.57 \\
7.37\end{array}$ \\
\hline Mediation & & & & & IndexLLCI & ULCI \\
\hline \multirow[t]{2}{*}{$\begin{array}{c}\text { Organic } \\
\text { food product-> } \\
\text { Perceived } \\
\text { quality->Abr->PI }\end{array}$} & & & & & \multicolumn{2}{|c|}{$0.08(0.0213,0.1623)$} \\
\hline & $\beta$ & $t(155)$ & $\beta$ & $\mathrm{t}(154)$ & $\beta$ & $\mathrm{t}(153)$ \\
\hline $\begin{array}{l}\text { Organic food } \\
\text { Product } \\
\text { x "white" space }\end{array}$ & 0.28 & 1.75 & -0.13 & -0.89 & 0.13 & 0.94 \\
\hline $\begin{array}{c}\text { Perceived quality } \\
\text { Abr }\end{array}$ & & & $0.64^{* * *}$ & 8.32 & $\begin{array}{l}0.63^{* * *} \\
0.35^{* * *}\end{array}$ & $\begin{array}{l}7.41 \\
4.79\end{array}$ \\
\hline Mediation & & & & & Index LLCI & ULCI \\
\hline $\begin{array}{c}\text { Organic food product } \\
\text { "white" space-> } \\
\text { Perceived } \\
\text { quality->Abr->PI }\end{array}$ & & & & & \multicolumn{2}{|c|}{$0.06(0.0025,0.1635)$} \\
\hline
\end{tabular}


Table 6. Direct effects in mediation model and bootstrap 95\% confidence intervals for indirect effects of organic food product (and organic food product with "white" space) on PI with perceived trustworthiness and Abr as mediating factors in Study 2.

\begin{tabular}{|c|c|c|c|c|c|c|}
\hline & \multicolumn{2}{|c|}{$\begin{array}{c}\text { Perceived } \\
\text { Trustworthiness }\end{array}$} & \multicolumn{2}{|c|}{ Abr } & \multicolumn{2}{|c|}{ PI } \\
\hline & $\beta$ & $\mathrm{t}(303)$ & $\beta$ & $\mathrm{t}(302)$ & $\beta$ & $\mathrm{t}(301)$ \\
\hline $\begin{array}{l}\text { Organic food } \\
\text { Product }\end{array}$ & 0.15 & 1.23 & -0.03 & -0.28 & $27^{* * *}$ & 2.79 \\
\hline Perceived trustworthiness & & & $\begin{array}{l}0.65^{* * *} \\
12.80\end{array}$ & & $0.57^{* * *}$ & 12.26 \\
\hline Abr & & & & & $0.38^{* * *}$ & 7.56 \\
\hline Mediation & & & & & IndexLLCI & ULCI \\
\hline \multirow[t]{2}{*}{$\begin{array}{l}\text { Organic food product-> } \\
\text { Perceived } \\
\text { trustworthiness->Abr- } \\
>\text { PI }\end{array}$} & & & & & \multicolumn{2}{|c|}{$0.04(-0.0192,0.1109)$} \\
\hline & $\beta$ & $\mathrm{t}(155)$ & $\beta$ & $\mathrm{t}(154)$ & $\mathrm{b}$ & $\mathrm{t}(153)$ \\
\hline $\begin{array}{c}\text { Organic food } \\
\text { Product } x \text { "white" space }\end{array}$ & $0.39 *$ & 2.38 & -0.19 & -1.26 & \multicolumn{2}{|c|}{0.0752} \\
\hline $\begin{array}{l}\text { Perceived trustworthiness } \\
\qquad \mathrm{Abr}\end{array}$ & & & $0.60^{* * *}$ & 8.14 & $\begin{array}{l}0.59 * * * \\
0.37 * * *\end{array}$ & $\begin{array}{l}7.24 \\
4.95\end{array}$ \\
\hline Mediation & & & & & IndexLLCI & ULCI \\
\hline $\begin{array}{l}\text { Organic food product } x \\
\text { "white" space-> } \\
\text { Perceived trustworthiness } \\
\text {->Abr->PI }\end{array}$ & & & & & \multicolumn{2}{|c|}{$0.09(0.0188,0.2011)$} \\
\hline
\end{tabular}

Perceived quality had a significant positive effect on Abr in both organic food product (vs. conventional food product) ( $\beta=0.68, \mathrm{SE}=0.05, \mathrm{t}=12.98, p<0.001$ ) and organic food product with extended "white" space (vs. organic food product with limited "white" space) $(\beta=0.64, \mathrm{SE}=0.16, \mathrm{t}=1.75, p<0.001$ ) models in support of Hypothesis H3b (Tables 4-6).

Perceived trustworthiness had a significant positive effect on Abr in both organic food product (vs. conventional food product) $(\beta=0.65, \mathrm{SE}=0.05, \mathrm{t}=12.81, p<0.001)$ and organic food product with extended "white" space (vs. organic food product with limited "white" space) $(\beta=0.60, \mathrm{SE}=0.07, \mathrm{t}=8.15, p<0.001)$ models in support of Hypothesis $\mathrm{H} 3 \mathrm{c}$ (Tables 4-6).

The analysis indicated that Abr had a significant positive effect on PI in the organic food product (vs. conventional food product) $(\beta=0.38, \mathrm{SE}=0.05, \mathrm{t}=7.56, p<0.001)$ and the organic food product with extended "white" space (vs. organic food product with limited "white" space) $(\beta=0.37, \mathrm{SE}=0.07, \mathrm{t}=4.85, p<0.001)$ models. Therefore, Hypothesis $\mathrm{H} 4$ is also accepted (Tables 4-6).

The analysis also demonstrated a significant serial mediation effect of organic food product on PI, via perceived naturalness and $\mathrm{Abr}(\beta=0.11 \mathrm{SE}=0.04,95 \% \mathrm{CI}[0.034$, 0.194]) (Hypothesis H5a) and via perceived quality and $\mathrm{Abr}(\beta=0.08 \mathrm{SE}=0.04,95 \% \mathrm{CI}$ $[0.021,0.162])$ (Hypothesis H5b) but not a significant serial mediation effect via perceived trustworthiness and Abr ( $\beta=0.04 \mathrm{SE}=0.03,95 \% \mathrm{CI}[-0.019,0.111])$ (Hypothesis H5c). Thus, Hypothesis H5a,b were supported and Hypothesis H5c was rejected (Tables 4-6).

Finally, the analysis provided evidence for a serial mediation effect of organic food product with extended "white" space on PI via perceived quality and Abr ( $\beta=0.06$ $\mathrm{SE}=0.04,95 \% \mathrm{CI}[0.002,0.163])$ (Hypothesis H6b) as well as via perceived trustworthiness and $\mathrm{Abr}(\beta=0.09 \mathrm{SE}=0.04,95 \% \mathrm{CI}[0.018,0.201])$ (Hypothesis $6 \mathrm{c})$ but there was not a significant serial mediation effect via perceived naturalness and $\mathrm{Abr}(\beta=0.05 \mathrm{SE}=0.04$, 
95\% CI [-0.001, 0.145]) (Hypothesis H6a). Thus, Hypothesis H6b and Hypothesis H6c were supported and Hypothesis 6a was rejected (Tables 4-6 and Figure 3).

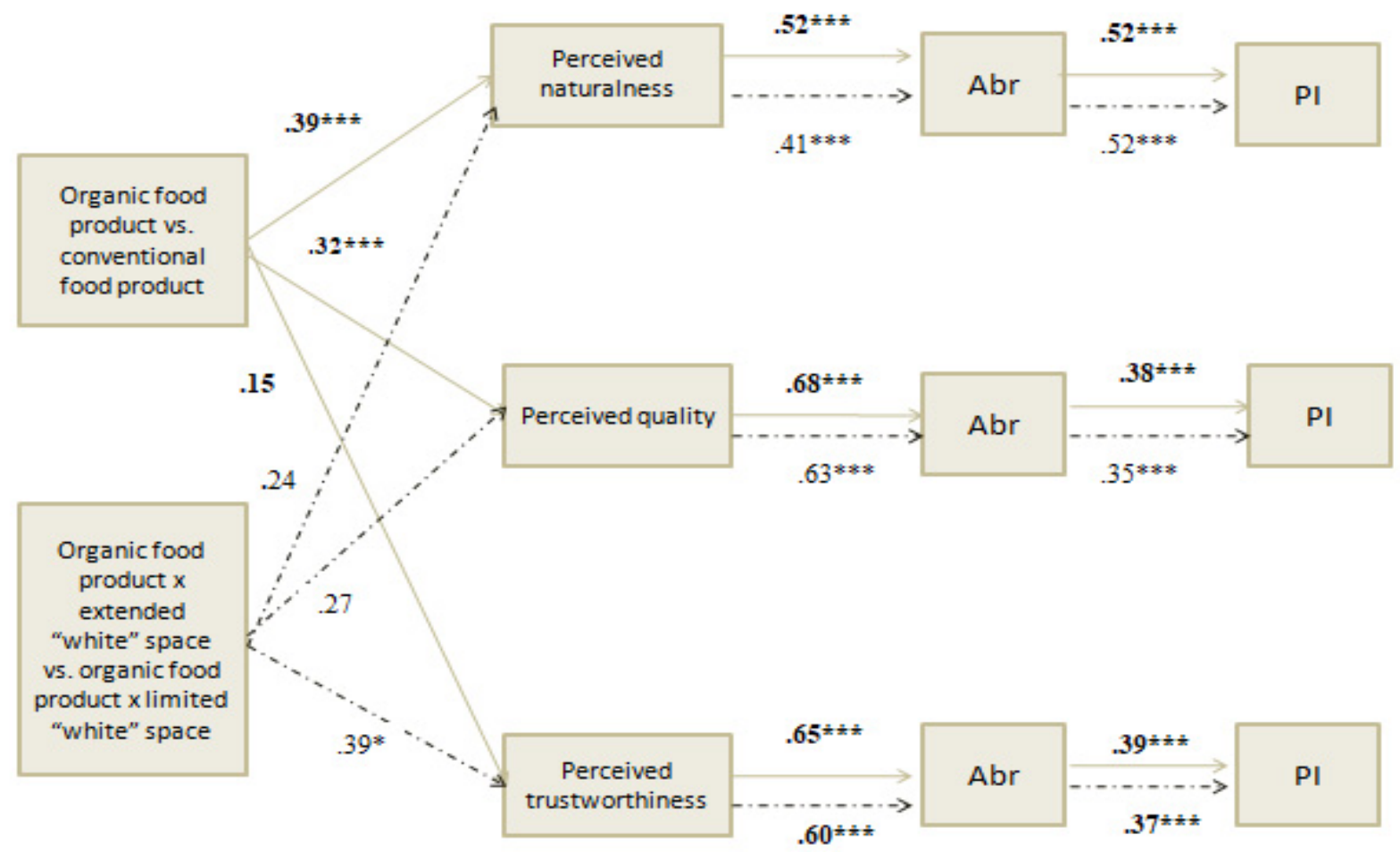

Figure 3. Path model 1 to 6 of Study 2. Note 1: Solid lines and bold numbers indicate the effects of organic food productdashed lines and italics indicate the effects of organic food product with "white" space. Note 2 : ${ }^{*} p<0.05$, $* * * p<0.001$.

\subsection{Discussion}

Study 2 exemplifies that organic foods and organic foods with extended "white" space on packaging generate higher levels of PI, via increased perceived naturalness, perceived quality, perceived trustworthiness and Abr. Perceived quality and perceived naturalness constitute significant pillars of organic products [17], enhanced by the use of extended "white" space [32]. However, it is proved that trustworthiness cannot be achieved by merely incorporating an organic claim on the food packaging. Aligned with previous studies [32], it is demonstrated that "white" space can make the organic foods seem more reliable and help build a trustworthy relationship between with consumers that will lead to positive Abr and PI.

\section{General Discussion}

\subsection{Theoretical Implications}

Study 1 validates the apparent business approach of incorporating extended "white" space in the packaging of organic (food) products. Most of the content analyzed organic products seem to be in the food sector, and include extended, and in shades of gray "white" space on their packaging. However, perhaps in an attempt to communicate the products' naturalness and healthfulness, marketers use different types of colors than shades of gray (i.e., green). Schuldt (2013) [118] for example, provides evidence that consumers who are motivated to buy healthy food products are swayed to choose packaging incorporating green color.

Study 2 examines the impact and the mechanism through which organic food products and especially when they incorporate an extended "white" space on their packaging affect $\mathrm{Abr}$ and PI. The present paper establishes that organic food products generate positive Abr which in turn affects PI, via enhanced perceived naturalness and quality of the product. 
Additionally, when the organic food product includes an extended "white" space in its packaging, it leads to positive Abr which in turn affects PI, via enhanced perceived quality and trustworthiness for the product.

First, the present study supports the hypothesis that organic food products lead to higher levels of perceived naturalness and perceived quality. This outcome is aligned with previous studies on organic products which prove that consumers often associate bio and organic products with notions of naturalness [72] and high quality [17]. In line with previous studies [119], it is demonstrated that the presence of an organic label is perceived as a symbol of quality, while it signifies that the product rejects any synthetic entity or human intervention, which implies its naturalness $[17,74]$. Thus, explicit signaling of organic is an important tool to establish and communicate perceptions of high quality and naturalness for organic foods [120].

However, this study failed to provide evidence that organic food products are considered as more trustworthy than the conventional ones. Prior research has confirmed that consumers are interested in the certification and labeling of organic food [121] and has proved that organic foods that include a label that contains proper information or health and nutrition claims are considered as trustworthy choices [122,123]. Nevertheless, the outcomes of the current study seem to be aligned with the opinion that consumers might have limited knowledge and awareness of natural, healthy and sustainable characteristics of organic food products. They are usually poorly informed about the benefits, the agriculture and the production processes of organic foods and thus unable to show trust in them and make purchasing decisions [46], especially by being provided merely with an explicit organic claim.

Second, the current research contributes to prior studies on the aesthetic dimensions of "white" space [30,32]. It establishes that the presence of extended "white" space in the packaging of organic food generates higher levels of perceived quality and perceived trustworthiness. In line with Pracejus, Olsen and O'Guinn (2006) [32], the present paper demonstrates that extended "white" space signifies high quality and trustworthiness for the product, through its associations with the minimalism. Along this vein, the outcomes of the current study are aligned with Pieters, Wedel and Batra (2010) [65,124], according to whom design simplicity takes over since package designs should communicate their messages quickly in stores. Moreover, this study supports Favier, Celhayb and PantinSohier (2019) [84], claims that brands with simple packaging designs are perceived as of higher quality than brands with more complex designs. Simple design requires specific skills and it is not as simple as one might imagine. The absence of decorations and visual noise in a simple design implies a "nothing-to-hide" aspect and thus it is associated with notions of trust and honesty according to Edwin (2016).On the contrary, Edwin (20160 [125], see also in Favier, Celhayb and Pantin-Sohier 2019 [84]) describes complex designs as manipulative and untrustworthy since it "feels like a well-dressed, eloquent door to door salesman trying his best to sell me cleaning solution ... it feels untrustworthy". The current study does not provide evidence that the presence of "white" space on organic food packaging will lead to increased perceived naturalness of the product as opposed to prior studies underlining that packaging design (i.e., the presence of extended "white" space) can lead consumers draw inferences about the sustainability values, such as perceived naturalness of the product [17].A possible explanation could be that the presence of multiple oranges on the packaging of the conventional product might signal high levels of freshness, healthiness and naturalness, too.

Third, the assumption that perceived naturalness, perceived quality and perceived trustworthiness positively affect Abr, stands for both organic food with and without extended "white" space condition. [In line with prior research [88] the outcomes of this study prove that perceived quality, perceived naturalness and perceived trustworthiness of the product lead consumers to exert more favorable attitudes and increased preference towards the brand. Thus, consumers' perceptions about the values of an organic product 
especially when combined with extended "white" space that signals high quality, clarity and trust [32] can positively affect consumers' brand evaluations.

Fourth, as indicated, Abr positively affects PI. As previously stated [91,126], Abr is a significant driver and predictor of consumers' behavior and buying decisions. Extending prior research [92,93], this study provides evidence that attitude can shape consumers' PI for organic food products and especially for those with extended "white" space in their packaging.

On a final note, the present paper reveals that organic foods can generate positive PI through enhanced perceptions of the products' naturalness and quality which in turn affect Abr. Nevertheless, the results of the study did not provide evidence on the serial mediation effect of organic food product on PI, via enhanced perceptions of the product's trustworthiness and Abr. Such outcomes prove that consumers' perceptions about a brand's characteristics (i.e., quality and naturalness) and values, can affect their attitudes and behaviors. The use of organic claims such as "Environmentally friendly" or " $100 \%$ Bio", or "Organic agriculture" etc., on the packaging of these products, might affect consumers' perceptions about the product itself. However, it is evident that merely using an organic claim on the packaging is not sufficient to build a trusted relationship with consumers. Previous studies have indicated that consumers are not well-informed, or they are at least confused about how organic agriculture methods are defined [46]. Along this line, the present study exemplifies that combining an organic claim on the food packaging with a proper packaging design might lead to enhanced levels of perceived trust. Particularly, the present study proved that an organic food product that incorporates an extended "white" space on its packaging generates positive PI via increased perceived quality and trustworthiness, which in turn positively affect Abr. Therefore, the current research confirms the study of Pracejus, Olsen and O'Guinn (2006) [32] according to which the presence of "white" space, through its associations with the minimalist movement in architecture and arts, infers high quality and trustworthiness for the brand. Nevertheless, there was no significant difference between the presence of extended versus limited "white" space with respect to perceptions of the product's naturalness. This might be attributed to the fact that incorporating the image of a fresh, healthy food on its packaging might also signal high levels of naturalness as "white" space does.

The current paper extends prior studies in three different ways. First, in the context of sustainable practices, most previous studies on organic foods mainly focus on agriculture methods and processes or on healthy ingredients [127-129]. However, there is limited work on the potential synergy between explicit organic claims and packaging aesthetics (i.e., "white" space) on consumers' perceptions about product values, such as quality, naturalness and trustworthiness, and their subsequent effect on Abr and PI. Razaei et al. (2019) [130] summarize a list of sustainable packaging criteria according to the European Organization for Packaging and the Environment (EUROPEN), the Sustainable Packaging Coalition and the Sustainable Packaging Alliance (SPA). Some of those criteria are the use of responsibly sourced, nontoxic and recycled materials, meeting market's criteria with respect to cost and performance and the packaging being beneficial, safe and healthy for individuals and communities. Most importantly, though, packaging should be designed in a holistic manner to optimize overall environmental performance, on the basis of "doing more with less". Given that "white" space constitutes one of the main design elements of minimalism which in turn is associated with sustainability [29], examining and manifesting the impact of its use on the packaging of organic products on Abr and PI becomes timely and significant. Shared values of minimalism (expressed via the presence of "white" space) and sustainability, such as clarity and simplicity [29] could highlight particular qualities of organic foods (i.e., perceived quality and trustworthiness) and in turn positively affect $\mathrm{Abr}$ and PI.

Third, the current study demonstrates that packaging design can build trust between organic food and consumers. As mentioned in previous studies, consumers have limited knowledge on organic, green or bio products and sometimes become confused about their 
sustainable characteristics, processes of production and content [46].Thus, they are uncertain about their purchases. Some factors that affect trust and reliability of an organic food product are health content, origin, organic labeling, local production, traditional methods, environmental awareness, labels with ingredients and food safety [131,132]. This study proves that an organic claim on the packaging might not be enough to generate higher levels of trust. Since trust is highly essential to organic food market, it is of utmost importance to discover other parameters that might contribute to its establishment, such as packaging design and aesthetics. Building on Petty and Cacioppo's (1984) [133] likelihood elaboration model, according to which peripheral cues (i.e., the appearance or the attractiveness of the source) can also drive consumers' persuasion, it is advocated that design simplicity, modesty and clarity promoted by the rhetorical "white" space could enhance consumers' trust and make them rely on the qualities of the organic food even if they have limited information or don't really understand the meaning of organic [134].

\subsection{Managerial Implications}

The outcomes of this study provide fruitful implications to brand, product and packaging managers, especially in the domain of organic food products. First, this study demonstrates that communicating the product's sustainable qualities via explicit organic or eco-friendly claims on its packaging could be beneficial and of strategic importance for brands. Explicit, organic claims on packaging enhance consumers' perceptions of high quality and naturalness which in turn can affect attitude towards the brand and purchase intention. Marketing managers can take advantage of sustainability direct claims on the organic food packaging in order to communicate the brands' identity in a visually recognizable and direct manner which could positively affect attitude and behavior. Considering that consumers sometimes have limited information about organic products, direct claims on packaging can help them establish specific perceptions with respect to the products values, and form positive attitude and behavior.

Some buyers of organic food products seem to be confused about the discrimination between organic and conventional food products. Organic products might lack some special value and trust in the eyes of consumers because of their higher prices or low availability $[135,136]$. This study underlines that the visual aspect and aesthetics of packaging design can affect consumers' perceptions, generating positive attitude and behavior towards brands, especially in the food domain. As it is proved in Study 1, "white" space is extensively used in the packaging of organic food products. Nevertheless, it has never been studied before whether this design tool is effective or not, and what are the factors through which "white" space might affect consumers' attitudes and intentions. Thus, the current study provides fruitful evidence to support the popular design trend in the business world, establishes the effectiveness of "white" space in the packaging of organic food products and unveils that the design style of a product's packaging infers messages depending on the extent of "white" space. Thus, marketers and designers are provided with a tool ("white" space) to develop the desired brand personality that will affect attitude and purchase behavior. Based on the associations and the shared values of minimalism and sustainability, such as truth, simplicity and clarity, the current study suggests that "white" space represents a rhetorical design element that communicates the product's sustainability values in an indirect manner, affecting perceptions of quality and trust, Abr and PI. "White" space de-clutters the packaging, leads the eye to the essence, and makes the product seem honest, without bombarding consumers with plenty of information and ornamentation.

Third, the present paper advocates that "white" space as a packaging design element in organic food products can establish trust between the product and consumers. To achieve a strong, trustworthy relationship between organic foods and consumers, marketing managers should not merely focus on directly communicating its sustainability values via organic claims and labeling with healthy ingredients, but rather use a more holistic, design approach, thereby, applying aesthetics on its packaging that communicates product's sustainable qualities in an indirect manner. 
All in all, the present study tests and reaffirms the strong relationship between minimal aesthetics, such as "white" space, and sustainability, in the context of marketing practices. Timelessness, functionality, beauty, clarity and truth communicated through simplicity, constitute the main shared tiers of minimalism and sustainability. In this vein, the current study provides evidence that these two popular trends "go hand in hand", via their conjoint emphasis on minimizing ornamentation and noise as way to help consumers recognize the real essence and sustainable values of the products.

\section{Limitations and Suggestions for Future Research}

Upon analysis of the research study, the following limitations are identified. First the current study focuses on a particular product category, that of organic foods. However, the content analysis in Study 1 demonstrated that organic foods and beverages constitute a large part of the organic market, yet not the only one. Thus, it is suggested that future research should consider the impact of different product categories, such as organic skincare and cosmetics, on consumers' perceptions, attitude and behavior. Second, Study 2 uses a convenience sample of graduate students. Therefore, it would be useful if future research replicates the study with diverse samples to attest the generalization of the findings. Third, another option to build on this research is to consider examining different types of consumer responses towards organic foods with extended "white" space in their packaging, such as attention, recall and recognition.

\section{Conclusions}

Overall, the present study manifests that both explicit and implicit sustainability claim son organic food packaging can be highly effective in terms of favorable attitudes and purchase intentions. Particularly, organic food products when incorporate explicit organic claims (i.e., " $100 \%$ organic") lead to positive attitude towards the brand and purchase intention via enhanced perceived naturalness and perceived quality. Additionally, the study demonstrates that the presence of extended "white" space in the packaging of organic food product also leads to positive attitude towards the brand and in turn to enhanced purchase intention via increased, perceived quality and trustworthiness. Perceptions of high quality, naturalness and trustworthiness of sustainable, organic food products can be enhanced due to the presence of "white" space, which according to previous studies [32] is associated with notions of high quality and trust. In addition, the current study builds on Zafarmand, Sugiyama and Watanabe (2003), according to which simple aesthetics (such as those communicated by "white" space) promote products' sustainable values and represent an important environmental aspect of design practices [29].

Funding: This research received no external funding.

Institutional Review Board Statement: Ethical review and approval were waived for this study, due to the characteristics of the survey the institution considered it not applicable.

Informed Consent Statement: Informed consent was obtained from all subjects involved in the study.

Data Availability Statement: The data presented in this study are available on request from the corresponding author. The data are not publicly available due to their containing information that could compromise the privacy of research participants.

Conflicts of Interest: The authors declare no conflict of interest.

\section{References}

1. Carrington, M.J.; Zwick, D.; Neville, B. The ideology of the ethical consumption gap. Mark. Theory 2015, 16, 21-38. [CrossRef]

2. Henninger, C.E.; Alevizou, P.J.; Oates, C.J. What is sustainable fashion? J. Fash. Mark. Manag. Int. J. 2016, 20, 400-416. [CrossRef]

3. Otto, S.; Strenger, M.; Maier-Nöth, A.; Schmid, M. Food packaging and sustainability—Consumer perception vs. correlated scientific facts: A review. J. Clean. Prod. 2021, 298, 126733. [CrossRef]

4. Martin, D.M.; Schouten, J.W. The answer is sustainable marketing, when the question is: What can we do? Rech. Appl. Mark. 2014, 29, 107-109. [CrossRef] 
5. Cooper, T. Longer Lasting Products: Alternatives to the Throwaway Society; CRC Press: Boca Raton, FL, USA, 2016.

6. Wilkie, W.L.; Moore, E.S. Expanding our understanding of marketing in society. J. Acad. Mark. Sci. 2011, 40, 53-73. [CrossRef]

7. Grönman, K.; Soukka, R.; Järvi-Kääriäinen, T.; Katajajuuri, J.M.; Kuisma, M.; Koivupuro, H.K.; Linnanen, L. Framework for sustainable food packaging design. Packag. Technol. Sci. 2013, 26, 187-200. [CrossRef]

8. Gilg, A.; Barr, S.; Ford, N. Green consumption or sustainable lifestyles? Identifying the sustainable consumer. Futures 2005, 37, 481-504. [CrossRef]

9. Barham, E. Towards a theory of values-based labeling. Agric. Hum. Values 2002, 19, 349-360. [CrossRef]

10. Paulos, B. Green power in perspective: Lessons from green marketing of consumer goods. Electr. J. 1998, 11, 46-55. [CrossRef]

11. Ramirez, E.; Jiménez, F.R.; Gau, R. Concrete and abstract goals associated with the consumption of environmentally sustainable products. Eur. J. Mark. 2015, 49, 1645-1665. [CrossRef]

12. Rettie, R.; Burchell, K.; Riley, D. Normalising green behaviours: A new approach to sustainability marketing. J. Mark. Manag. 2012, 28, 420-444. [CrossRef]

13. Mazar, N.; Zhong, C.-B. Do green products make us better people? Psychol. Sci. 2010, 21, 494-498. [CrossRef]

14. Scalvedi, M.L.; Saba, A. Exploring local and organic food consumption in a holistic sustainability view. Br. Food J. 2018, 120, 749-762. [CrossRef]

15. Azzurra, A.; Massimiliano, A.; Angela, M. Measuring sustainable food consumption: A case study on organic food. Sustain. Prod. Consum. 2018, 17, 95-107. [CrossRef]

16. Hemmerling, S.; Hamm, U.; Spiller, A. Consumption behaviour regarding organic food from a marketing perspective-A literature review. Org. Agric. 2015, 5, 277-313. [CrossRef]

17. Magnier, L.; Schoormans, J.; Mugge, R. Judging a product by its cover: Packaging sustainability and perceptions of quality in food products. Food Qual. Prefer. 2016, 53, 132-142. [CrossRef]

18. Lee, H.J.; Yun, Z.S. Consumers' perceptions of organic food attributes and cognitive and affective attitudes as de-terminants of their purchase intentions toward organic food. Food Qual. Prefer. 2015, 39, 259-267. [CrossRef]

19. Mother Earth Living. 14 Sustainable Food Companies You Can Trust-Eat Healthy-Natural Home \& Garden. 2012. Available online: Motherearthliving.com (accessed on 15 June 2021).

20. Kilbourne, W.; McDonagh, P.; Prothero, A. Sustainable consumption and the quality of life: A macromarketing challenge to the dominant social paradigm. J. Macromarketing 1997, 17, 4-24. [CrossRef]

21. Prothero, A.; Fitchett, J.A. Greening capitalism: Opportunities for a green commodity. J. Macromarketing 2000, 20, 46-55. [CrossRef]

22. McDonagh, P.; Prothero, A. Sustainability marketing research: Past, present and future. J. Mark. Manag. 2014, 30, 1186-1219. [CrossRef]

23. Forbes, P. Sustainable Packaging in 2021 and Beyond. Ideas \& Examples. Pack-Help. 2021. Available online: https: / / packhelp.com/sustainable-packaging/?epik=dj0yJnU9RTM3aEdTb21uMHllaEdQa2VXVE9BcINHdzNKZU1IV1QmcD0 wJm49R3NuY0FvRnZlbXR6UVJtb0JyckN3dyZ0PUFBQUFBR0VidW5Z (accessed on 15 June 2021).

24. Liao, G.Z.; Chen, C.H. Comparing human aesthetic perception of basic geometric forms to the principles of golden section. In Proceedings of the 5th Asian Design Conference, National University, Seoul, Korea, 11-13 October 2001.

25. Mossetto, G. Aesthetics and Economics; Kluwer Academic Publishers: Dordrecht, The Netherlands, 1993 ; p. 216.

26. Walker, S.; Dorsa, E. Making design work—Sustainability, product design and social equity. J. Sustain. Prod. Des. 2001, 1, 41-48. [CrossRef]

27. Magnier, L.; Crié, D. Communicating packaging eco-friendliness: An exploration of consumers' perceptions of eco-designed packaging. Int. J. Retail. Distrib. Manag. 2015, 43, 350-366. [CrossRef]

28. Zafarmand, S.J.; Sugiyama, K.; Watanabe, M. Aesthetic and sustainability: The aesthetic attributes promoting product sustainability. J. Sustain. Prod. Des. 2003, 3, 173-186. [CrossRef]

29. Chim, I.S.; Blebea, I. Minimalism: An Optimal Aesthetic for the Sustainable Design. Available online: https://atna-mam.utcluj. ro/index.php/Acta/article/view/421 (accessed on 15 June 2021).

30. Margariti, K.; Hatzithomas, L.; Boutsouki, C.; Zotos, Y. A path to our heart: Visual metaphors and "white" space in advertising aesthetic pleasure. Int. J. Advert. 2021, 1-40. [CrossRef]

31. Pracejus, J.W.; O'Guinn, T.C.; Olsen, G.D. When white space is more than "burning money": Economic signaling meets visual commercial rhetoric. Int. J. Res. Mark. 2013, 30, 211-218. [CrossRef]

32. Pracejus, J.W.; Olsen, G.D.; O'Guinn, T.C. How nothing became something: White space, rhetoric, history, and meaning. J. Consum. Res. 2006, 33, 82-90. [CrossRef]

33. Berger, V. Social norm-based gamification to promote eco-friendly food choice. J. Consum. Mark. 2019, 36, 666-676. [CrossRef]

34. Sun, Y.; Wang, S. Understanding consumers' intentions to purchase green products in the social media marketing context. Asia Pac. J. Mark. Logist. 2019, 32, 860-878. [CrossRef]

35. Krystallis, A.; Fotopoulos, C.; Zotos, Y. Organic consumers' profile and their willingness to pay (WTP) for selected organic food products in Greece. J. Int. Consum. Mark. 2006, 19, 81-106. [CrossRef]

36. Kahneman, D.; Knetsch, J.L. Valuing public goods: The purchase of moral satisfaction. J. Environ. Econ. Manag. 1992, 22, 57-70. [CrossRef]

37. Bhaskaran, S.; Polonsky, M.; Cary, J.; Fernandez, S. Environmentally sustainable food production and marketing: Opportunity or hype? Br. Food J. 2006, 108, 677-690. [CrossRef] 
38. Magnusson, M.K.; Arvola, A.; Hursti, U.K.K.; Åberg, L.; Sjödén, P.O. Choice of organic foods is related to perceived consequences for human health and to environmentally friendly behaviour. Appetite 2003, 40, 109-117. [CrossRef]

39. Bigsby, H.; Ozanne, L.K. The purchase decision: Consumers and environmentally certified wood products. For. Prod. J. 2002, 52, 100-105.

40. Vis, J.K.; Standish, M. How to make agri-food supply chains sustainable: Unilever's perspective. Sustain. Dev. Int. 2003, 3, 111-117.

41. Menon, A.; Menon, A. Enviropreneurial marketing strategy: The emergence of corporate environmentalism as market strategy. J. Mark. 1997, 61, 51-67. [CrossRef]

42. Beamon, B.M. Designing the green supply chain. Logist. Inf. Manag. 1999, 12, 332-342. [CrossRef]

43. Verbeke, W.; Ward, R.W. Consumer interest in information cues denoting quality, traceability and origin: An application of ordered probit models to beef labels. Food Qual. Prefer. 2006, 17, 453-467. [CrossRef]

44. Hartnett, J.L.; Schechter, S.H.; Kropp, D.H.; Garvin, D.A. Managing quality: The strategic and competitive edge. Acad. Manag. Rev. 1988, 13, 656. [CrossRef]

45. Lee, W.C.J.; Shimizu, M.; Kniffin, K.M.; Wansink, B. You taste what you see: Do organic labels bias taste perceptions? Food Qual. Prefer. 2013, 29, 33-39. [CrossRef]

46. Vermeir, I.; Verbeke, W. Sustainable food consumption: Exploring the consumer "attitude-behavioral intention" gap. J. Agric. Environ. Ethics 2006, 19, 169-194. [CrossRef]

47. Van der Grijp, N.M.; den Hond, F. Green Supply Chain Initiatives in the European Food and Retailing Industry; Institute for Environmental Studies, Vrije Universiteit: Amsterdam, The Netherlands, 1999.

48. Kumar, D.S.; Purani, K.; Sahadev, S. Visual servicescape aesthetics and consumer response: A holistic model. J. Serv. Mark. 2017, 31, 556-573. [CrossRef]

49. Wang, J.; Hsu, Y. Does sustainable perceived value play a key role in the purchase intention driven by product aesthetics? Taking smartwatch as an example. Sustainability 2019, 11, 6806. [CrossRef]

50. Underwood, R.L. The communicative power of product packaging: Creating brand identity via lived and mediated experience. J. Mark. Theory Pract. 2003, 11, 62-76. [CrossRef]

51. McNeal, J.U.; Ji, M.F. Children's visual memory of packaging. J. Consum. Mark. 2003, 20, 400-427. [CrossRef]

52. Jordan, P.W. Human factors for pleasure in product use. Appl. Ergon. 1998, 29, 25-33. [CrossRef]

53. Bloch, P.H. Seeking the ideal form: Product design and consumer response. J. Mark. 1995, 59, 16-29. [CrossRef]

54. Nancarrow, C.; Wright, L.T.; Brace, I. Gaining competitive advantage from packaging and labelling in marketing communications. Br. Food J. 1998, 100, 110-118. [CrossRef]

55. Mugge, R.; Dahl, D.W.; Schoormans, J.P. What you see, is what you get? Guidelines for influencing consumers' perceptions of consumer durables through product appearance. J. Prod. Innov. Manag. 2018, 35, 309-329. [CrossRef]

56. Creusen, M.E.; Veryzer, R.W.; Schoormans, J.P. Product value importance and consumer preference for visual complexity and symmetry. Eur. J. Mark. 2010, 44, 1437-1452. [CrossRef]

57. Creusen, M.E.H.; Schoormans, J.P.L. The different roles of product appearance in consumer choice. J. Prod. Innov. Manag. 2004, 22, 63-81. [CrossRef]

58. Bloch, P.H. Product design and marketing: Reflections after fifteen years. J. Prod. Innov. Manag. 2011, 28, 378-380. [CrossRef]

59. Thomas, F.; Capelli, S. The effect of the number of ingredient images on package evaluation and product choice. Rech. Appl. Mark. 2018, 33, 6-30. [CrossRef]

60. Underwood, R.L.; Klein, N.M.; Burke, R.R. Packaging communication: Attentional effects of product imagery. J. Prod. Brand Manag. 2001, 10, 403-422. [CrossRef]

61. Steenis, N.D.; van der Lans, I.A.; van Herpen, E.; van Trijp, H.C. Effects of sustainable design strategies on consumer preferences for redesigned packaging. J. Clean. Prod. 2018, 205, 854-865. [CrossRef]

62. Balconi, M.; Sebastiani, R.; Angioletti, L. A neuroscientific approach to explore consumers' intentions towards sustainability within the luxury fashion industry. Sustainability 2019, 11, 5105. [CrossRef]

63. Magnier, L.; Schoormans, J. Consumer reactions to sustainable packaging: The interplay of visual appearance, verbal claim and environmental concern. J. Environ. Psychol. 2015, 44, 53-62. [CrossRef]

64. Stevanovich, V. A reading of interpretative models of minimalism architecture. J. Fac. Archit. 2013, 30, 181-194.

65. Pieters, R.; Wedel, M.; Batra, R. The stopping power of advertising: Measures and effects of visual complexity. J. Mark. 2010, 74, 48-60. [CrossRef]

66. Kwan, C.M.; Dai, X.; Wyer, R.S., Jr. Contextual influences on message persuasion: The effect of empty space. J. Consum. Res. 2017, 44, 448-464. [CrossRef]

67. Berlyne, D.E.; Boudewijns, W.J. Hedonic effects of uniformity in variety. Can. J. Psychol. Rev. Can. Psychol. 1971, 25, 195. [CrossRef]

68. Ulrich, R.S. Aesthetic and Affective Response to Natural Environment; Plenum Press: New York, NY, USA, 1983 ; pp. 85-125.

69. Karvonen, K. The beauty of simplicity. In Proceedings of the 2000 Conference on Universal Usability, Arlington, VA, USA, 16-17 November 2000; pp. 85-90.

70. Kasar, P.M.; Tribhuwan, C.S.; Khode, J.G. Innovative packaging of medicines. Asian J. Res. Pharm. Sci. 2020, 10, 56-60. [CrossRef]

71. Aboud, D.; Al Adawy, N.Y.; Moawad, M.G. Fostering value co-creation as a determinant for customers' satisfaction in the corporate identity. Int. Des. J. 2019, 9, 249-259. 
72. Sijtsema, S.J.; Onwezen, M.C.; Reinders, M.J.; Dagevos, H.; Partanen, A.; Meeusen, M. Consumer perception of bio-based products-An exploratory study in 5 European countries. NJAS-Wagening. J. Life Sci. 2016, 77, 61-69. [CrossRef]

73. Tobler, C.; Visschers, V.H.; Siegrist, M. Eating green. Consumers' willingness to adopt ecological food consumption behaviors. Appetite 2011, 57, 674-682. [CrossRef]

74. Rozin, P.; Spranca, M.; Krieger, Z.; Neuhaus, R.; Surillo, D.; Swerdlin, A.; Wood, K. Preference for natural: Instrumental and ideational/moral motivations, and the contrast between foods and medicines. Appetite 2004, 43, 147-154. [CrossRef] [PubMed]

75. Moore, G.E.; Baldwin, T. Principia Ethica; Cambridge University Press: Cambridge, UK, 1993.

76. Tenbült, P.; de Vries, N.K.; Dreezens, E.; Martijn, C. Perceived naturalness and acceptance of genetically modified food. Appetite 2005, 45, 47-50. [CrossRef] [PubMed]

77. Dano, F. Packaging: Une approche sémiotique. Rech. Appl. Mark. 1996, 11, 23-35. [CrossRef]

78. Orth, U.R.; Malkewitz, K. Holistic package design and consumer brand impressions. J. Mark. 2008, 72, 64-81. [CrossRef]

79. Becker, L.; van Rompay, T.J.; Schifferstein, H.N.; Galetzka, M. Tough package, strong taste: The influence of pack-aging design on taste impressions and product evaluations. Food Qual. Prefer. 2011, 22, 17-23. [CrossRef]

80. Petersen, M.; Brockhaus, S. Dancing in the dark: Challenges for product developers to improve and communicate product sustainability. J. Clean. Prod. 2017, 161,345-354. [CrossRef]

81. Li, M.; Chapman, G.B. Why do people like natural? Instrumental and ideational bases for the naturalness preference. J. Appl. Soc. Psychol. 2012, 42, 2859-2878. [CrossRef]

82. Battcock, G. Minimal: A Critical Anthology; University of California Press: Berkeley, CA, USA, 1995.

83. Lin, S.-W.; Lo, L.Y.-S.; Huang, T.K. Visual complexity and figure-background color contrast of e-commerce websites: E_ects on consumers' emotional responses. In Proceedings of the 2016 49th Hawaii International Conference on System Sciences (HICSS), Koloa, HI, USA, 5-8 January 2016; IEEE: Piscataway, NJ, USA, 2016; pp. 3594-3603.

84. Favier, M.; Celhay, F.; Pantin-Sohier, G. Is less more or a bore? Package design simplicity and brand perception: An application to Champagne. J. Retail. Consum. Serv. 2018, 46, 11-20. [CrossRef]

85. Sharma, N.; Varki, S. Active white space (AWS) in logo designs: Effects on logo evaluations and brand communication. J. Advert. 2018, 47, 270-281. [CrossRef]

86. McEachern, M.; McClean, P. Organic purchasing motivations and attitudes: Are they ethical? Int. J. Consum. Stud. 2002, 26, 85-92. [CrossRef]

87. Carlson, L.; Grove, S.; Kangun, N.; Polonsky, M.J. An international comparison of environmental advertising: Substantive vs. associative claims. J. Macromarketing 1996, 16, 57-68. [CrossRef]

88. Dawar, N.; Parker, P. Marketing universals: Consumers' use of brand name, price, physical appearance, and retailer reputation as signals of product quality. J. Mark. 1994, 58, 81-95.

89. Chen, M.; Wang, Y.; Yin, S.; Hu, W.; Han, F. Chinese consumer trust and preferences for organic labels from different regions: Evidence from real choice experiment. Br. Food J. 2019, 21, 1521-1535. [CrossRef]

90. Martinho, G.; Pires, A.; Portela, G.; Fonseca, M. Factors affecting consumers' choices concerning sustainable packaging during product purchase and recycling. Resour. Conserv. Recycl. 2015, 103, 58-68. [CrossRef]

91. Ajzen, I. The theory of planned behavior. Organ. Behav. Hum. Decis. Processes 1991, 50, 179-211. [CrossRef]

92. Chen, M.-F. Consumer attitudes and purchase intentions in relation to organic foods in Taiwan: Moderating effects of food-related personality traits. Food Qual. Prefer. 2007, 18, 1008-1021. [CrossRef]

93. Smith, S.; Paladino, A. Eating clean and green? Investigating consumer motivations towards the purchase of organic food. Australas. Mark. J. 2010, 18, 93-104. [CrossRef]

94. Ragavan, N.; Mageh, R. A study on service quality perspectives and customer satisfaction in new private sector banks. IOSR J. Bus. Manag. 2013, 7, 26-33. [CrossRef]

95. Werner, J.; Alvensleben, R.V. Consumer attitudes towards organic food in Germany (F.R.). Int. Symp. Hortic. Econ. Manag. 2011, 7, 155. [CrossRef]

96. van Doorn, J.; Verhoef, P. Willingness to pay for organic products: Differences between virtue and vice foods. Int. J. Res. Mark. 2011, 28, 167-180. [CrossRef]

97. Chen, Y.S.; Chang, C.H. Enhance green purchase intentions: The roles of green perceived value, green perceived risk, and green trust. Manag. Decis. 2012, 50, 502-520. [CrossRef]

98. Reheul, D.; Mathijs, E.; Relaes, J. Elements for a Future View with Respect to Sustainable Agri- and Horticulture in Flanders. In Sustainable Agriculture; Stedula: Ghent, Belgium, 2001.

99. Dehghani, M.; Kim, K.J. The effects of design, size, and uniqueness of smartwatches: Perspectives from current versus potential users. Behav. Inf. Technol. 2019, 38, 1143-1153. [CrossRef]

100. Lavie, T.; Tractinsky, N. Assessing dimensions of perceived visual aesthetics of web sites. Int. J. Human-Computer Stud. 2004, 60, 269-298. [CrossRef]

101. Charter, M.; Tischner, U. Sustainable Solutions: Developing Products and Services for the Future; Routledge: London, UK, 2017.

102. Bragd, A. The Organising of Green Products: Five Case Studies of Green Technological Innovation Products; University of Gothenburg: Gothenburg, Sweden, 1997.

103. James, P. The sustainable cycle: A new tool for product development and design. J. Sustain. Prod. Des. 1997, 2, 56-57. 
104. Vidales Giovannetti, M.D. El Mundo del Envase. Manual para el Diseno y Produccio'n de Envases y Embalajes; Editorial Gustavo Gili: Mexico City, Mexico, 1995; p. 90.

105. Aday, M.S.; Yener, U. Assessing consumers' adoption of active and intelligent packaging. British Food J. 2015, 117, 157-177. [CrossRef]

106. Bloch, P.H.; Brunel, F.F.; Arnold, T.J. Individual differences in the centrality of visual product aesthetics: Concept and measurement. J. Consum. Res. 2003, 29, 551-565. [CrossRef]

107. Khan, K.; Ali, M. Impact of electronic word of mouth on consumer purchase intention in footwear industry of Pakistan. Kuwait Chapter Arab. J. Bus. Manag. Rev. 2017, 6, 52-63. [CrossRef]

108. Thorson, E. Experiment, Laboratory, Design of The International Encyclopedia of Media Psychology; Wiley: Hoboken, NJ, USA, 2020; pp. $1-7$.

109. Mhlophe, B. Consumer Purchase intentions towards organic food: Insights from South Africa. Bus. Soc. Sci. J. 2016, 1, 1-32. [CrossRef]

110. Binninger, A.-S. Perception of naturalness of food packaging and its role in consumer product evaluation. J. Food Prod. Mark. 2015, 23, 251-266. [CrossRef]

111. Dodds, W.B.; Monroe, K.B.; Grewal, D. Effects of price, brand, and store information on buyers' product evaluations. J. Mark. Res. 1991, 28, 307-319.

112. Ohanian, R. Construction and validation of a scale to measure celebrity endorsers' perceived expertise, trustworthiness, and attractiveness. J. Advert. 1990, 19, 39-52. [CrossRef]

113. Geuens, M.; Pelsmacker, P.D. Need for cognition and the moderating role of the intensity of warm and humorous advertising appeals. ACR Asia-Pac. Adv. 1998, 1, 1-32.

114. Lafferty, B.A.; Goldsmith, R.E. Corporate credibility's role in consumers' attitudes and purchase intentions when a high versus a low credibility endorser is used in the ad. J. Bus. Res. 1998, 44, 109-116. [CrossRef]

115. Sheehan, K.; Atkinson, L. Green Advertising and the Reluctant Consumer; Routledge: London, UK, 2016.

116. Hayes, J.R. The Complete Problem Solver; Routledge: London, UK, 2013.

117. Pritschet, L.; Powell, D.; Horne, Z. Marginally significant effects as evidence for hypotheses: Changing attitudes over four decades. Psychol. Sci. 2016, 27, 1036-1042. [CrossRef]

118. Schuldt, J.P. Does green mean healthy? Nutrition label color affects perceptions of healthfulness. Heal. Commun. 2013, 28 , 814-821. [CrossRef]

119. Alvensleben, R. von Padberg, D. Consumer behavior. In Agro-Food Marketing; Padberg, D., Ritson, C., Albisu, L., Eds.; Oxon Routledge: New York, NY, USA, 1997; pp. 209-224.

120. Janssen, M.; Hamm, U. Product labelling in the market for organic food: Consumer preferences and willingness-to-pay for different organic certification logos. Food Qual. Prefer. 2012, 25, 9-22. [CrossRef]

121. Delgado-Ballester, E.; Munuera-Alemán, J.L. Brand trust in the context of consumer loyalty. Eur. J. Mark. 2001, 35, 1238-1258. [CrossRef]

122. Miller, L.M.S.; Cassady, D.L. The effects of nutrition knowledge on food label use. A review of the literature. Appetite 2015, 92, 207-216. [CrossRef] [PubMed]

123. Akowska-Biemans, S. Polish consumer food choices and beliefs about organic food. Br. Food J. 2011, 113, 122-137. [CrossRef]

124. Pieters, R.; Wedel, M. Attention capture and transfer in advertising: Brand, pictorial, and text-size effects. J. Mark. 2004, 68, 36-50. [CrossRef]

125. Edwin, T. Logo Decode: From Logo Design to Branding; Promopress: Barcelona, Spain, 2016.

126. Conner, M.; Armitage, C. Extending the theory of planned behavior: A review and avenues for further research. J. Appl. Soc. Psychol. 1998, 28, 1429-1464. [CrossRef]

127. Teng, C.C.; Wang, Y.M. Decisional factors driving organic food consumption: Generation of consumer purchase intentions. Br. Food J. 2015, 117, 1066-1081. [CrossRef]

128. Batte, M.T.; Hooker, N.H.; Haab, T.C.; Beaverson, J. Putting their money where their mouths are: Consumer willingness to pay for multi-ingredient, processed organic food products. Food Policy 2007, 32, 145-159. [CrossRef]

129. Lohr, L. Factors affecting international demand and trade in organic food products. In Changing Structure of Global Food Consumption and Trade; Economic Research Service/USDA: Washington, DC, USA, 2001; pp. 67-79.

130. Rezaei, J.; Papakonstantinou, A.; Tavasszy, L.; Pesch, U.; Kana, A. Sustainable product-package design in a food supply chain: A multi-criteria life cycle approach. Packag. Technol. Sci. 2018, 32, 85-101. [CrossRef]

131. Basha, M.B.; Mason, C.; Shamsudin, M.F.; Hussain, H.I.; Salem, M.A. Consumers attitude towards organic food. Procedia Econ. Finance 2015, 31, 444-452. [CrossRef]

132. Fernqvist, F.; Ekelund, L. Credence and the effect on consumer liking of food-A review. Food Qual. Preference 2014, 32, 340-353. [CrossRef]

133. Petty, R.E.; Cacioppo, J.T. The effects of involvement on responses to argument quantity and quality: Central and peripheral routes to persuasion. J. Personal. Soc. Psychol. 1984, 46, 69. [CrossRef]

134. Hughner, R.S.; McDonagh, P.; Prothero, A.; Shultz, C.J.; Stanton, J. Who are organic food consumers? A compilation and review of why people purchase organic food. J. Consum. Behav. 2007, 6, 94-110. [CrossRef] 
135. Fotopoulos, C.; Krystallis, A. Organic product avoidance: Reasons for rejection and potential buyers' identification in a countrywide survey. Br. Food J. 2002, 104, 233-260. [CrossRef]

136. Fotopoulos, C.; Krystallis, A. Purchasing motives and profile of the Greek organic consumer: A countrywide survey. Br. Food J. 2002, 104, 730-765. [CrossRef] 